\title{
IMPROVING IRRIGATION PERFORMANCE OF RAISED BED WHEAT USING THE WINSRFR MODEL UNDER EGYPTIAN CONDITIONS
}

\author{
Samir M. Ismail ${ }^{1}$, Abdelsamie Thabet ${ }^{2}$, Ahmed Abdel El-Al ${ }^{3}$, Abdelaziz I. Omara ${ }^{4{ }^{*}}$ \\ ${ }^{1}$ Prof. of Irrigation and Drainage Eng. Systems, Ag. and Biosystems Eng. Dept., Fac. of Ag., \\ Alexandria U., Egypt. \\ ${ }^{2}$ MSc Stud. Ag. and Biosystems Eng. Dept., Fac. of Ag., Alexandria U., Egypt. \\ ${ }^{3}$ Lecturer of Irrigation and Drainage Eng. Systems, Ag. and Biosystems Eng. Dept., Fac. of Ag., \\ Alexandria U., Egypt. \\ ${ }^{4}$ Assoc. Prof. of Irrigation and Drainage Eng. Systems, Ag. and Biosystems Eng. Dept., Fac. of Ag., \\ Alexandria U., Egypt. \\ *E-mail: abdelaziz.omara@alexu.edu.eg
}

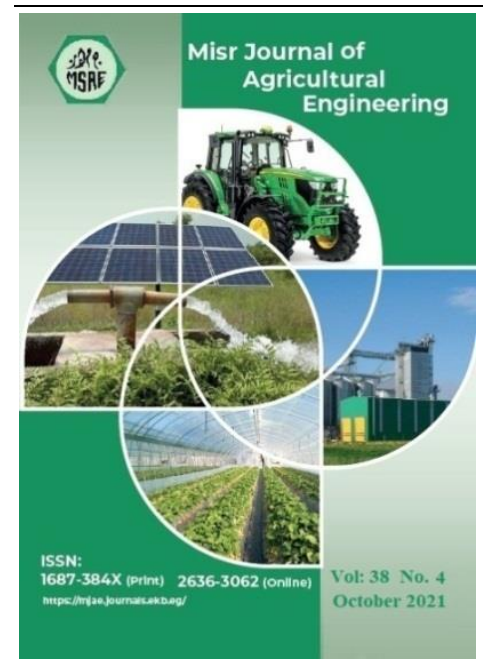

(C) Misr J. Ag. Eng. (MJAE)
Keywords:

Raised bed; Irrigation performance; Optimizing, WinSRFR

\section{ABSTRACT}

Field experiments were carried out at the Sakha Agricultural Research Station in the governorate of Kafr el Sheikh, Egypt to evaluate and optimize the irrigation performance of raised beds wheat using the WinSRFR model during 2019/2020. Raised beds (RB130 cm, and RB100 cm) were prepared using Raised bed planter. The model calibration was based on a close match between the observed and simulated curves of advance and recession time. Simulation Analysis World was used to evaluate the current irrigation performance of the raised bed furrows $(R B)$ and the flat basin (FB) methods. The simulation analysis shows that for $R B 130 \mathrm{~cm}, R B 100 \mathrm{~cm}$, and $F B$ irrigation systems, the application efficiencies were 80, 64, 43\%, and distribution uniformities were $86,88,90 \%$, and deep percolation losses were $20,36,56 \%$, and adequacy were 1.07, 1.37, 2.08\%, respectively. Physical Design World was used to optimize and develop different design strategies. The results showed that irrigation performance decreased with the increasing length of furrow and basin, so extremely long lengths should be avoided because they result in decreased efficiency and uniformity, as well as big deep percolation loss. Managing the inflow rate and irrigation cut-off through Operation Analysis World can increase application efficiency and reduce deep percolation losses by more than $15 \%, 60 \%$, and $17 \%, 33 \%$, and $23 \%, 17.5 \%$ respectively, for $R B 130 \mathrm{~cm}, R B 100 \mathrm{~cm}$, and $F B$.

\section{INTRODUCTION}

$\mathrm{W}$ ater supplies in Egypt are limited due to current intensive agricultural production and are limiting crop production in the newly reclaimed lands. Agriculture in Egypt depends heavily on irrigation (El-Halim, 2013). As a result, Egypt has suffered from severe water scarcity in recent years, while the Nile River is the main source of freshwater, and Egypt's agricultural sector is also considered to be one of the highest water consuming sectors (Khalifa et al., 2019). 
The agricultural sector absorbs more than $84 \%$ of the water resources available (El-Beltagy et al., 2008). Surface irrigation is the main irrigation method in ancient, cultivated lands with a total area of 6.5 million feddan (2.73 million ha). In this method of irrigation, water use constitutes $61 \%$ of the total water supply despite its very low water efficiency in the field. Improving this system will save large quantities of irrigation water, which will be used to extend horizontally (ICARDA, 2020).

The raised bed system is an enhanced surface irrigation technique that increases water productivity and allows water usage to more effective in irrigated systems. It could be carried out efficiently by farmers themselves. Irrigation water is added to the base of the furrows in this system. Less water is required for irrigation, because furrows collect water effectively, instead of spreading it over the entire surface (like border irrigation). Beds can differ in width from 0.25 to 2.00 meters as well as the number of rows of crops per bed. Often the width of the bed is defined by the width of the machine used, either the width of the tractor axle corresponding to the furrow width or multiples of the furrow width (Roth et al., 2005). This technology was spread in 22 governorates, as part of a national initiative by the Egyptian Government on self-sufficiency in wheat production, for sustainable agricultural intensification on a large scale (Ismail S., 1993) and (Swelam, 2017).

Irrigation management requires the distribution of water to all areas of the irrigated field. That is an engineering challenge and it can be efficiently achieved by minimizing losses and maximizing uniformity by optimizing inflow rate, application depth, time to cut-off and field design (Akbar, 2017). The prediction of the behaviour of surface irrigation is complicated due to several analytical problems (N. Pascual-Seva et al., 2013). However, nowadays, it is technically possible to draw up and make operational suggestions based on simulations (Strelkoff, T. S., \& Clemmens, A. J., 2007).

The development of IT facilities has led to the creation of several simulation models and optimization of surface irrigation plans. These models are both valuable tools at the design and management phases of surface systems. Simulation models used for irrigation design purposes help to optimize surface irrigation variables, such as field length, field slope and define flow rate. In other words, the models can help the designer to make decisions about the appropriate values of the variables that give the best performance.

One of the most widely used models WinSRFR, one of the modern surface irrigation hydraulic simulation models. It was developed by the USDA Agricultural Research Service. It involves the integration of the SRFR surface irrigation (border, basin, and furrow) program, level basin design program BASIN (Clemmens et al . 1995) and sloping border-strip program BORDER (Strelkoff et al. 1996). This latest software also contains extra functionality and is based on the Windows environment. WinSRFR uses simplified forms of momentum equations (i.e. zero-inertia or kinematic-wave models). This modelling technique was established by the USDA-ALARC (2009) to be sufficiently effective when used under the proper conditions, and also computationally faster.

Thus, the objective of this study was to evaluate the current raised bed irrigation system and using WinSRFR model to identify scenarios for improving irrigation performance. 


\section{MATERIALS AND METHODS}

\section{Site Description}

Field experiments were carried out at the Sakha Agricultural Research Station in Egypt's Kafr el-sheik Governorate to evaluate and optimize the irrigation performance of raised bed (RB) and traditional flat basin (FB) using the WinSRFR model during 2019/2020.

The site is located at $30^{\circ} 57^{\prime} \mathrm{E}$ longitude and $31^{\circ} 07^{\prime} \mathrm{N}$ latitude, with an elevation of approximately 6 meters above mean sea level. According to Klute (1987), the particle size distribution and some soil water constants are presented in Table (1).

Table (1): Some physical characteristics and some soil water constants of the studied site before

\begin{tabular}{|c|c|c|c|c|c|c|c|c|}
\hline \multirow{2}{*}{$\begin{array}{c}\text { Soil } \\
\text { Depth, } \\
\text { cm. }\end{array}$} & \multicolumn{3}{|c|}{ Particle Size Distribution } & \multirow{2}{*}{$\begin{array}{l}\text { Texture } \\
\text { classes }\end{array}$} & \multirow{2}{*}{ F.C \% } & \multirow{2}{*}{ P.W.P \% } & \multirow{2}{*}{ AW \% } & \multirow{2}{*}{$\begin{array}{c}\mathrm{Bd} \\
\mathrm{g} \mathrm{cm}^{-3}\end{array}$} \\
\hline & Sand $\%$ & Silt \% & Clay \% & & & & & \\
\hline $0-15$ & 16.6 & 19.4 & 64.0 & Clay & 47.3 & 25.0 & 22.3 & 1.16 \\
\hline $15-30$ & 19.2 & 17.9 & 62.9 & Clay & 39.9 & 21.5 & 18.4 & 1.19 \\
\hline $30-45$ & 17.6 & 19.8 & 62.6 & Clay & 38.1 & 21.1 & 17.0 & 1.23 \\
\hline $45-60$ & 18.8 & 19.6 & 61.6 & Clay & 37.4 & 20.3 & 17.1 & 1.31 \\
\hline Mean & 18.1 & 18.8 & 62.8 & Clay & 40.7 & 22.0 & 18.7 & 1.22 \\
\hline
\end{tabular}

Where: F.C $\%=$ Soil field capacity, P.W.P $\%=$ Permanent wilting point, AW $\%=$ Available water and $\mathrm{Bd}\left(\mathrm{g} \mathrm{cm}^{-3}\right)=$ Soil bulk density

\section{Preparation of Land and Sowing of Crop}

The land at the experimental site was prepared by deep plowing followed by laser land levelling. Raised beds (RB) were prepared using a raised bed shaper with planter which was a research support from ICARDA project, figures (1 and 2). Two RB furrow spacing $130 \mathrm{~cm}$ (RB130) and $100 \mathrm{~cm}$ (RB100) as well as the traditional flat basin (FB) methods were tested and evaluated.

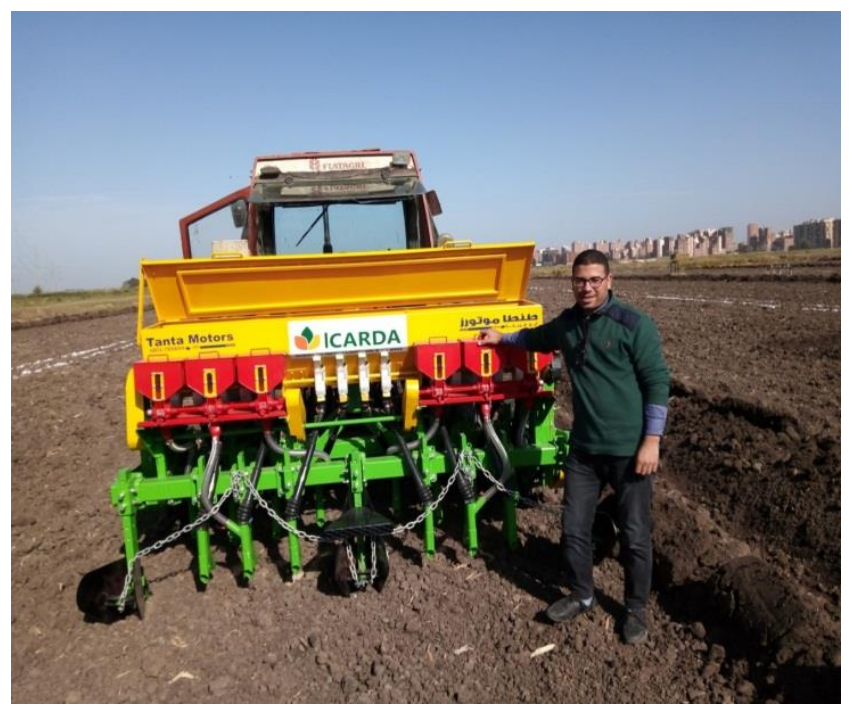

Figure 1: The Raised bed planter machine that had been used in this experiment to prepare soil for raised beds planting (from ICARDA project) 


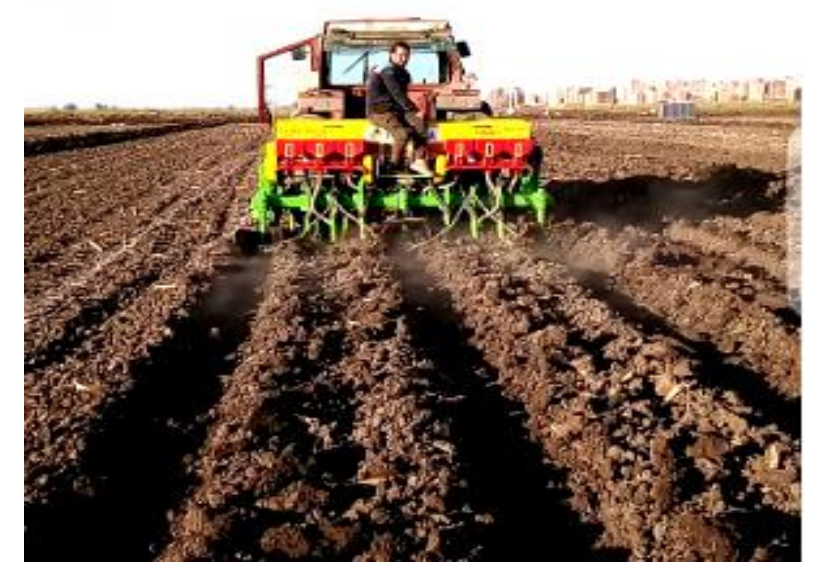

Figure 2: Prepared soil for raised-bed planting

\section{Experimental Design}

The experimental site consisted of three borders divided into three different treatment groups, with three replicates for each treatment. The irrigation performance was evaluated for two-bed treatments: (i) RB130 cm and (ii) RB100 cm, in addition to FB. Each RB130 cm replicate comprised of six furrows and five beds and each RB100 cm replicate had six furrows and seven beds. The field lengths were $72 \mathrm{~m}$ per treatment and all raised bed furrows had a slope of $\sim 0.0001 \mathrm{~m} / \mathrm{m}$ but for the flat basin, the slope was $\sim 0.0002 \mathrm{~m} / \mathrm{m}$. The detailed layout of the experimental field is shown in Fig (3).

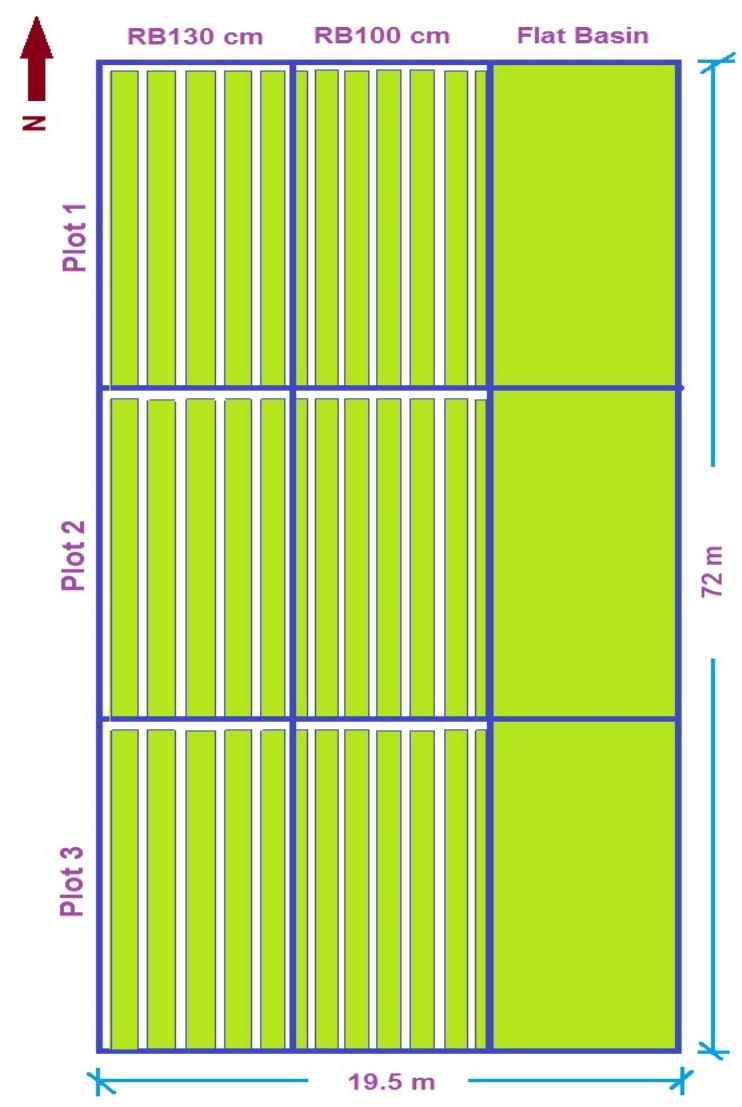

Figure 3: Layout of experimental site 


\section{Control Unit}

The pump $6.5 \mathrm{hp}$ with a gasoline engine and $900 \mathrm{~L} / \mathrm{min}$ inflow rate at $3600 \mathrm{rpm}$ under 26 $\mathrm{m}$ water head and $75 \mathrm{~mm}$ inside diameter of water outlet.

Based on the data of physical soil analysis that is given in Table (1), the required depth value was calculated according to the following equation:

$$
\begin{gathered}
\text { Dreq }=\left(\theta_{f c}-\theta_{p w p}\right) \times D \times \rho_{b} \times d e p \\
\text { Dreq }=(40.7 \%-22 \%) \times 0.60 \times 1.22 \times 0.50=0.06844 \mathrm{~m}=68.44 \mathrm{~mm}
\end{gathered}
$$

\section{Simulation Modeling of Surface Irrigation Systems}

Surface irrigation systems were analyzed using the WinSRFR 4.1.3 (Bautista et al., 2012). The WinSRFR integrates tools for irrigation system estimation, operational analysis, and irrigation system design as shown in Fig (4). Field irrigation data and system descriptions were put into the model through the Event Analysis World tool to estimate the soil infiltration functions i.e. $a$, and $k$ parameters. The calibrated infiltration parameters have been used to optimize and develop various design strategies using the Design World of the model. In the optimization stage using Operation Analysis World, the model was configured to develop performance contours as a function of inflow rate and cutoff time for the known (furrow set/border) width. Required depth (Dreq) is another important input parameter for surface irrigation simulation. Dreq can be defined as the average depth ( $\mathrm{mm})$ required filling the root zone. The maximum required depth can be calculated from the total soil moisture holding capacity, i.e. the total moisture available between field capacity and wilting point (TAM) as well as the allowable depletion fraction thereof, termed the readily available moisture content (RAM) as discussed by Jurriëns et al., (2001). Figure (5) shows the methodological flow chart of the study.

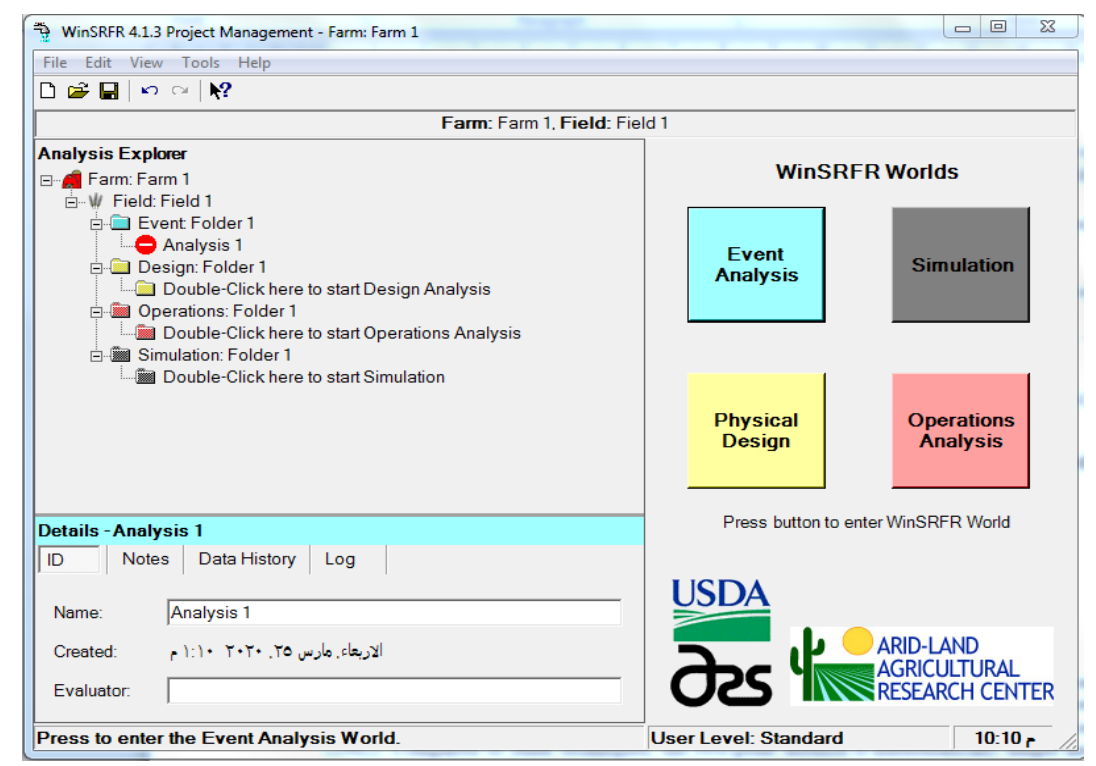

Figure 4: WinSRFR management windows

\section{Measurements}

\section{System Geometry data}

Furrow dimensions including furrow spacing (FS); top width (TW); middle width (MW); bottom width (BW), and furrow depth (D), were measured for all furrows at the field head, 
middle, and tail segments. The average dimensions of all furrows was determined to obtain the overall averages of furrow structure parameters before irrigation for RB130 cm and RB100 $\mathrm{cm}$ as shown in Fig (6).

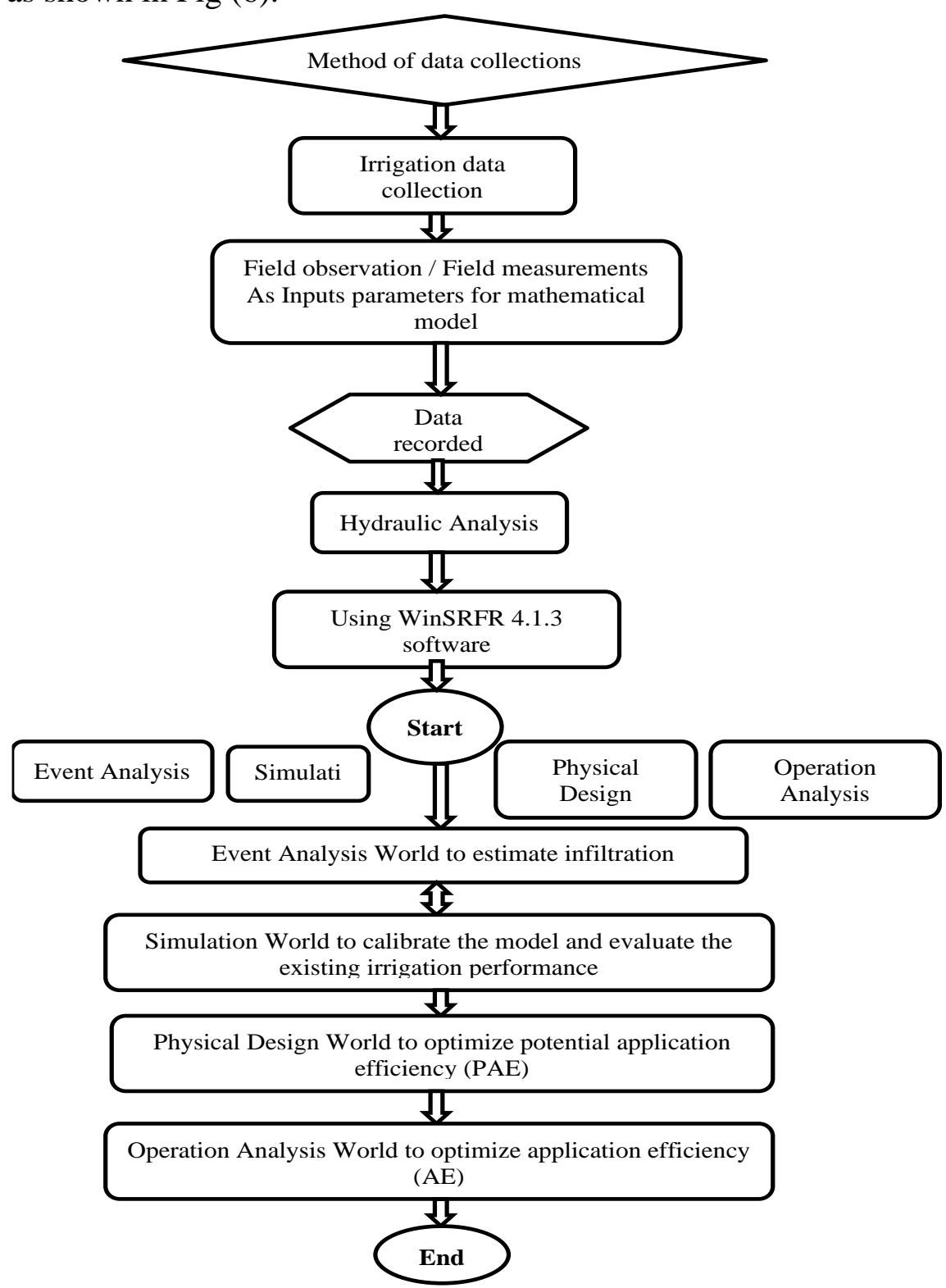

Figure 5: Methodological flow chart of the study
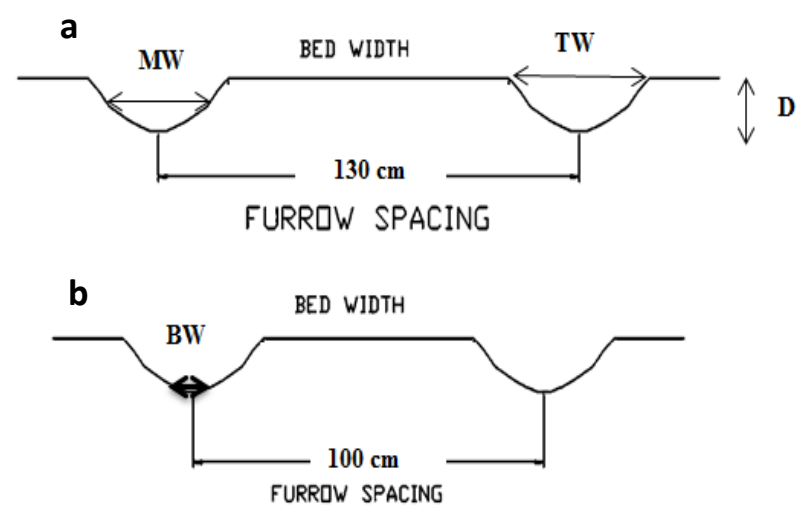

Figure 6: Raised bed furrow dimensions (TW: top width, MW: middle width, BW: bottom width, FS: furrow spacing and D: furrow depth); (a) RB130 cm and (b) $R B 100 \mathrm{~cm}$ 


\section{Water flow $(\mathbf{Q})$ and cutoff time $\left(\mathbf{T}_{\mathbf{C O}}\right)$}

The flow of water (Q) was continuously determined by a flow meter (ISCO 2150 area velocity flow module; Teledyne ISCO Inc., Lincoln, NE, USA) installed on a small pump located at the water entrance to the experimental plots, irrigation water discharge was calculated based on pre-and post-irrigation flow meter readings, dividing by time to cut-off as the following equation:

Where:

$$
Q=\frac{\mathrm{v} 2-\mathrm{v} \mathbf{1}}{\mathrm{Tco}}
$$

$$
\begin{aligned}
& \mathrm{Q}=\text { discharge with } \mathrm{m}^{3} / \mathrm{h} \\
& \mathrm{V} 1=\text { reading the flow meter before irrigation, } \mathrm{m}^{3} \\
& \mathrm{~V} 2=\text { reading the flow meter after irrigation ended, } \mathrm{m}^{3} \\
& \text { Tco }=\text { irrigation water cut off time, hours. }
\end{aligned}
$$

The inflow rate was assumed to be uniformly distributed over the different simultaneously irrigated furrows, so for the raised bed irrigation system, q was measured as the average Q divided by the total number of irrigated furrows.

\section{Water Advance Rate}

The advance of water observed during the irrigation event by recording the arrival time of the water at the fixed stations constructed along with the experimental plot of the raised beds and the flat basin. According to field observations, irrigation inflow to the field was cut-off after the water advance reached the tail end of furrow irrigation fields to ensure wetting of the bed middle.

\section{Advance \& Recession}

The objective of measuring advance and recession times was to find the manning roughness coefficient $(n)$ values and infiltration parameters that minimized the difference between observed and simulated advance and recession times that were used to test irrigation efficiency (Bautista et al., 2009). For all experimental irrigation treatments of raised bed (RB100 and RB130) and flat basin (FB) systems, the advance and recession times were measured at fixed stations $(6 \mathrm{~m}, 12 \mathrm{~m}, 18 \mathrm{~m}$, and $24 \mathrm{~m})$ constructed along the monitored plots. The infiltration opportunity time along the furrow length at each station was calculated for each furrow as the time difference between the water disappears and the first beginning to advance along the furrow at the same position.

\section{Infiltration}

This study focused on only the two methods. The first method is to observe the advance rate and use WinSRFR Event Analysis World to calculate infiltration $a \& k$ with the two-point method. This method will provide accurate estimates of infiltration function when the rate of soil infiltration is high and the storage phase is very short in comparison to the advance time (Peter Waller, 2015) (this means that the volume of surface storage is very small compared to the volume of infiltration (Bautista et al., 2012)). And the other method is a double-ring infiltrometer to estimate the basic infiltration rate of the soil. 


\section{Two-point method}

Elliot and Walker (1982) developed a method for determining the constants of the infiltration equation of Kostiakov, based on the relationship between the advances and the advance time of the waterfront in the furrow. The general equations used to calculate the constants are as follows:

$$
\begin{array}{cc}
a=\frac{\ln \left(\frac{V_{L}}{V_{0.5 L}}\right)}{\ln \left(\frac{t_{L}}{t_{0.5 L}}\right)} & K=\frac{V_{L}}{T_{L}^{a} \sigma_{z}} \\
\sigma_{z}=\frac{a+r(1-a)+1}{(1+a)(1+r)} & f_{\circ}=\frac{Q_{\text {in }}-Q_{\text {out }}}{L}
\end{array}
$$

Where:

$\sigma_{\mathrm{z}}=$ the subsurface shape factor

$\mathrm{L}=$ furrow length $(\mathrm{m})$

$\mathrm{t}_{\mathrm{L}}, \mathrm{t}_{0.5 \mathrm{~L}}=$ advance time at distance of $\mathrm{L}$ and $\mathrm{L} / 2(\mathrm{~min})$

$\mathrm{Q}_{\text {in }}$ and $\mathrm{Q}_{\text {out }}=$ in and out flow discharge $\left(\mathrm{m}^{3} / \mathrm{min}\right)$

$r=$ power of advance trajectory in relationship to time

$\mathrm{X}=\mathrm{pt}^{\mathrm{r}}$ where $\mathrm{X}$ is the distance from the inlet, $\mathrm{p}$ and $r$, are constants

For the two-point advance method, fixed signs were positioned as a station to determine the advance time of the water during the irrigation event. Two points, the first at the mid-distance point and another at the downstream end of the furrow, are registered during irrigation water advance and were used to calculate infiltration parameters in the WinSRFR 4.1.3 software. The same previous steps were taken to measure advance time in the flat basin system.

\section{Double-ring infiltrometer}

The soil basic infiltration rate was measured in the field by using a double-ring infiltrometer. The depth of the water at the start time was quickly recorded along with the elapsed time using a stopwatch and ruler. The depth of water infiltrated into the soil was determined using an elapsed time interval until the infiltration rate reached a constant value. It's important to note that the experiment lasted about 7 hours. In this experiment, the elapsed time interval at the initial and final depth of infiltration was measured with 2-30 min intervals until the steady infiltration depth was obtained. As a result, the infiltration rate and cumulative infiltration were estimated as the two basic parameters.

\section{Manning's roughness coefficient, $n\left(\mathrm{~s} \mathrm{~m}^{-1 / 3}\right)$}

Manning's roughness coefficient is the most essential factor for the design and assessment of surface irrigation ( Harun-ur-Rashid, 1990). Abbasi (2013), noted that Manning's roughness coefficient is generally considered to be between 0.02 and 0.04 for furrows and changes with time and position (Mazarei et al., 2021). In this study, Manning's roughness coefficient was based on the recommended values of the NRCS (USDA-SCS, 1991) and this coefficient was great-tuned in the light of the roughness of the furrow bed and the presence of planting (Pascual-Seva et al., 2013). Simulations with WinSRFR 4.1.3 were performed to define $n$ values that reduced the difference between simulated and observed advance and recession times used to evaluate irrigation performance of the raised bed and flat basin system (Bautista, et al., 2009). 


\section{Irrigation efficiencies}

The following irrigation efficiencies were estimated using simulation modeling as described by Bautista et al., (2012):

\section{Application Efficiency (AE):}

It is the ratio of the infiltrated depth that corresponds to the irrigation target $\left(D_{z}\right)$ to the actual irrigation depth added $\left(D_{\text {app }}\right)$ or the water obtained at the field inlet. When $D_{z}$ equals the low quarter infiltration depth $\left(\mathrm{D}_{\mathrm{lq}}\right)$, the application efficiency is referred to as the low quarter application efficiency $\left(\mathrm{AE}_{\mathrm{lq}}\right)$, and when $\mathrm{Dz}$ equals the minimum infiltration depth $\left(D_{\min }\right)$, the application efficiency is referred to as the minimum application efficiency $\left(\mathrm{AE}_{\min }\right)$.

2. Potential Application Efficiency (PAE):

Attainable AE when the inflow rate and time to cut-off are such that Dlq = Dreq (required irrigation depth) is referred to as the low-quarter potential application efficiency (PAElq), and when Dmin = Dreq is referred to as the minimum potential application efficiency (PAEmin).

3. Adequacy $(\mathrm{AD})$ :

Is the $D_{\min }$ to $D_{\text {req }}$ to Adequacy ratio based on minimum infiltration depth $\left(\mathrm{Ad}_{\min }\right)$ and the $\mathrm{D}_{\mathrm{lq}}$ to $\mathrm{D}_{\text {req }}$ ratio based on the low quarter $\left(\mathrm{AD}_{\mathrm{lq}}\right)$.

4. Distribution Uniformity (DU):

It is the ratio of $D_{\min }$ to $D_{\text {inf }}$ (the average depth of the water infiltrated) for $D U_{\min }$, and the ratio of $D_{\text {lq }}$ to $D_{\text {inf }}$ for DUlq. Uniformity refers to the homogeneity of the infiltrated water throughout the field and depends on the design and maintenance of the system.

\section{* Calibration and Validation of WinSRFR}

Model calibration for irrigation event was obtained by modifying infiltration parameters and current design characteristics using the Event Analysis World and Elliott-Walker (1982) method in the WinSRFR model (Bautista et al., 2019). Modifying infiltration parameters and existing design characteristics can be accomplished by a trial-and-error approach used to estimate infiltration parameters (Bautista et al., 2019). These parameters and the Manning coefficient were used in the simulation analysis world of the WinSRFR model to obtain simulated advance and recession curves, which were compared to the measured curves and if the fit was weak, new combinations of $n, a$, and $k$ were validated over an approximate range, and this method was repeated until the best-fit match was achieved between the simulated and measured curves (Mazarei et al., 2021). Once the model is successful, WinSRFR has been used for simulating the hydraulic performance of furrows (Biru Dechasa Sima, 2018). Via this study, the results of the software package were compared to the data observed and validated by the WinSRFR model for use in the conditions of field soil.

\section{RESULTS AND DISCUSSION}

\section{Cumulative infiltration depth and infiltration rate:}

Based on the Double-ring infiltrometer results, the basic infiltration rate was $4.02 \mathrm{~mm} / \mathrm{hr}$, indicating that the structural assessment of soil structure quality is extremely poor according to Geeves et al. (1990). Figure (7) illustrates the cumulative infiltration and infiltration rate curves, as well as the basic infiltration rate, for the experiment site. 


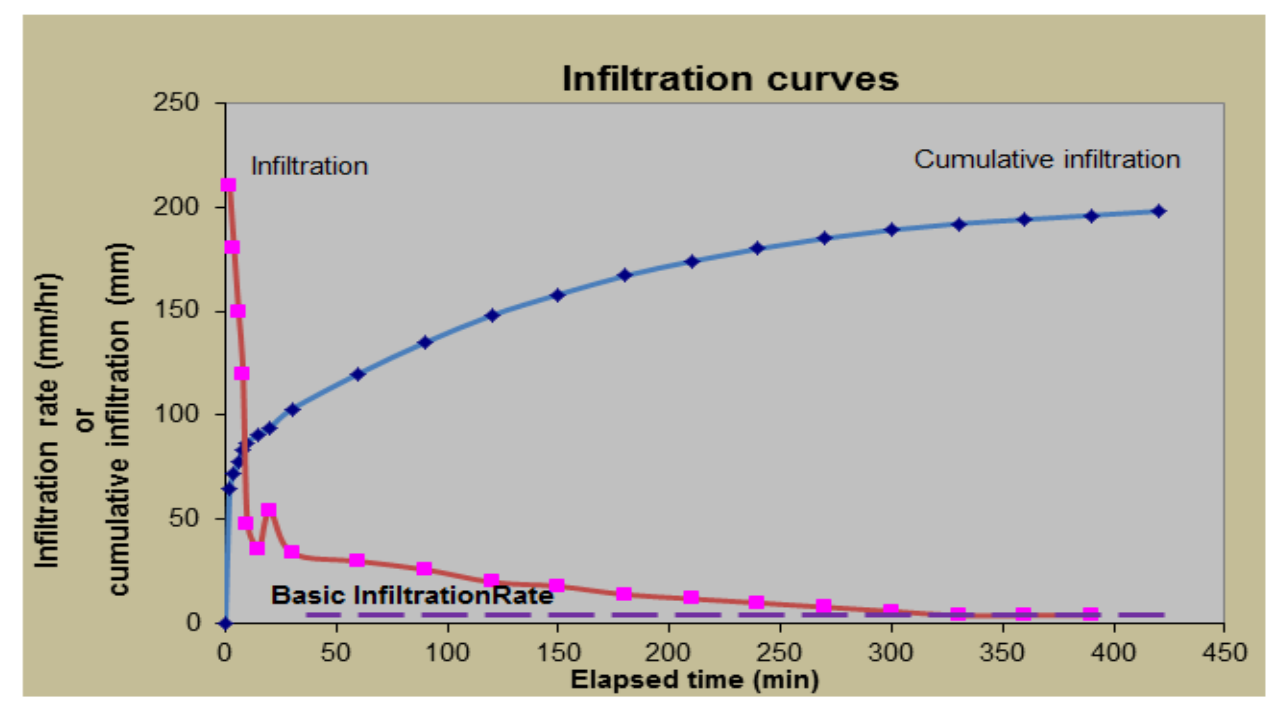

Figure 7: Curves of cumulative infiltration depth and infiltration rate

\section{Observed Advanced and Recession Curve}

Figures (8 and 9) illustrate the observed advance and recession curves for RB130 cm and RB100 cm during $1^{\text {st }}$ irrigation respectively. The inflow rate and cutoff time for RB130 cm furrow treatment were $2 \mathrm{l} / \mathrm{sec}$ and $22.2 \mathrm{~min}$, and for RB100 $\mathrm{cm}$ were $2 \mathrm{l} / \mathrm{sec}$ and $21.6 \mathrm{~min}$, respectively. Figure (10) shows the advance and recession curves of the waterfront during the first irrigation for the FB. The inflow rate and cutoff time were $9.67 \mathrm{l} / \mathrm{sec}$ and $42.6 \mathrm{~min}$, respectively.

It is noticeable from Figures $(8,9$, and 10) the recession wave began to appear from the end of the furrow or basin due to cutting off the irrigation as soon as the water wave reached the end of the furrow or basin (storage period was very small), thus the time of the water wave remaining above the surface of the earth was short compared to at the head of the furrow or basin, and also due to the weak slope of the ground.

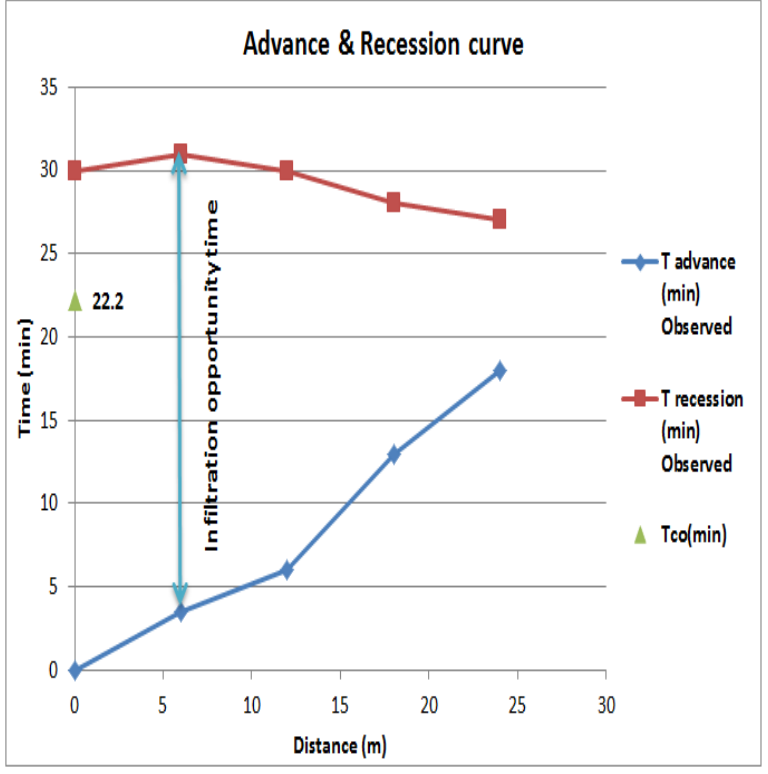

Figure 8: Observed advance and recession curves for RB $130 \mathrm{~cm}_{\text {during }} 1^{\text {st }}$ irrigation

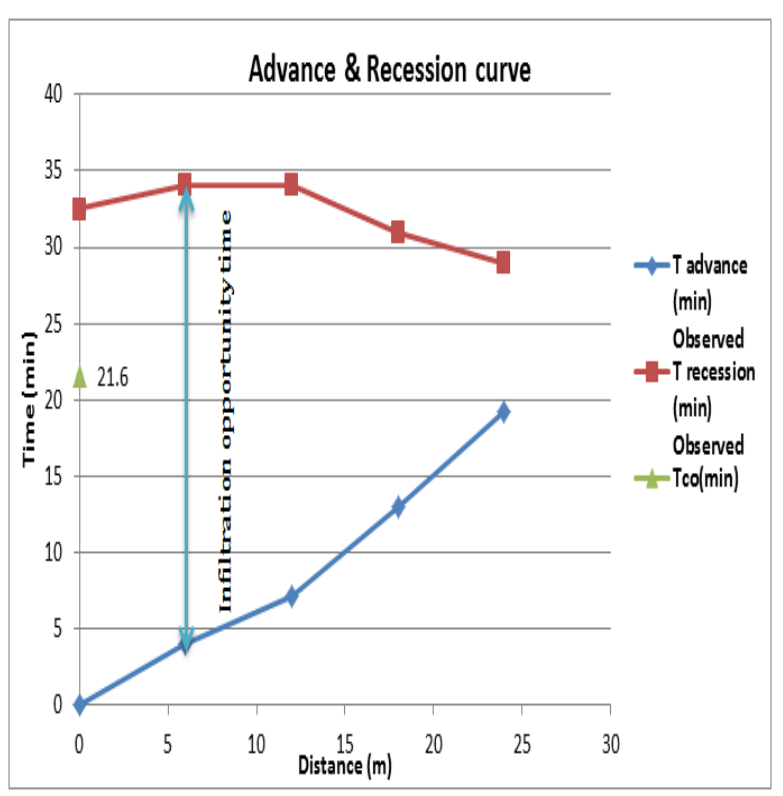

Figure 9: Observed advance and recession curves for RB $100 \mathrm{~cm}$ during 1st irrigation 


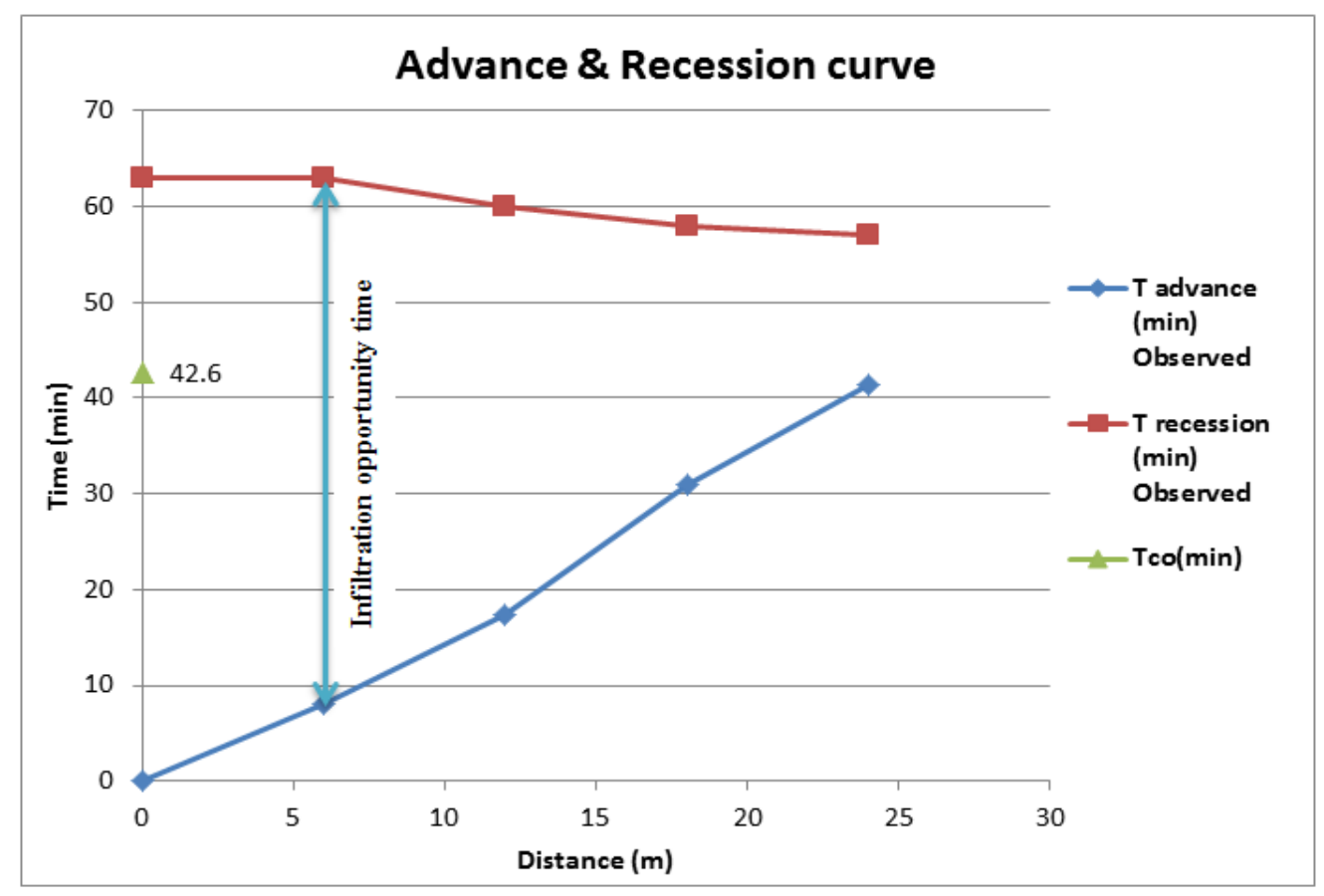

Figure 10: Observed advance and recession curves for flat basin (FB) during $1^{\text {st }}$ irrigation

\section{Estimate Infiltration Parameters Using WinSRFR}

Based on field data, Event Analysis World (using Elliott and Walker's two-point method analysis) was used to determine the infiltration parameters for irrigation systems. The soil infiltration functions i.e. $a$, and $k$ parameters of the Kostiakov equation were computed for raised beds and flat basin irrigation systems.

\section{Event Analysis procedure for RB130 cm, RB100 and FB}

Data in Table (2) is entered into Event Analysis World to obtain infiltration parameters. For example, the following paragraph shows how to obtain the infiltration parameters for RB130 $\mathrm{cm}$ :

RB Furrow Irrigation Event Analysis: In the event analysis world furrow was selected, required depth $(69 \mathrm{~mm})$ was entered while Elliott and Walker's two-point method analysis was selected. In the system geometry field length L $(24 \mathrm{~m})$, furrow spacing F.S $(1.3 \mathrm{~m})$, number of furrows per set (1). In the cross-section, part trapezoid from field data was selected and the edit data button was clicked to enter the top width $(487 \mathrm{~mm})$, middle width $(280 \mathrm{~mm})$, bottom width $(140 \mathrm{~mm})$, maximum depth $(133 \mathrm{~mm})$, then save data $\&$ close was clicked and field slope $S_{0}(0,0001 \mathrm{~m} / \mathrm{m})$ was entered. The roughness method based on Manning's $n(0.04)$ was selected. In the inflow/runoff tab inflow rate Q $(2 \mathrm{l} / \mathrm{s})$, cut-off time $(0.37 \mathrm{hr})$ with no cutback and blocked end was selected. In the field measurement tab, the two-point advance method that involves distance and time at point one was $12 \mathrm{~m}, 0.1 \mathrm{hr}$, respectively, distance and time at point two was $24 \mathrm{~m}, 0.3 \mathrm{hr}$. In the execution tab after clicking on estimate $a \& k$ tab, WinSRFR will calculate Kostiakov parameters $(a=0.405$ and $k=124.78 \mathrm{~mm} / \mathrm{hra})$ as shown in Figure (11).

For RB100 cm and FB, the Kostiakov parameters as the event analysis procedures output were $a=0.309$ and $k=147.401 \mathrm{~mm} / \mathrm{hr}^{\mathrm{a}}$, and $a=0.208$ and $k=171.759 \mathrm{~mm} / \mathrm{hr}^{\mathrm{a}}$, respectively. 
Table 2: Field data for $\mathrm{RB130} \mathrm{cm}, \mathrm{RB100}$ and $\mathrm{FB}$ as inputs to the event analysis procedure

\begin{tabular}{lccc} 
Variable & $\begin{array}{c}\text { Value for RB130 } \\
\text { cm }\end{array}$ & Value for RB100 cm & Value for FB \\
\hline System type & Furrow & Furrow & Basin \\
Length , m & 24 & 24 & 24 \\
width , m & - & - & 6.5 \\
Maximum Depth, mm & - & - & 300 \\
Spacing, F.S , m & 1.30 & 1.00 & - \\
Number per set & 1 & 1 & - \\
Top width , mm & 487 & 487 & - \\
Middle Width , mm & 280 & 280 & - \\
Bottom width , mm & 140 & 140 & - \\
Max depth , mm & 133 & 133 & - \\
Manning's n & 0.04 & 0.04 & 0.04 \\
Slope , m/m & 0.0001 & 0.0001 & 0.0002 \\
Q, L/s & 2 & 2 & 9.7 \\
$\mathrm{~T}_{\text {co }}$, hr & 0.37 & 0.36 & 0.71 \\
Point 1, m & 12 & 12 & 12 \\
Point 2, m & 24 & 24 & 24 \\
Time at point 1, hr & 0.10 & 0.12 & 0.29 \\
Time at point 2, hr & 0.30 & 0.32 & 0.69 \\
Downstream condition & blocked & blocked & Blocked \\
\hline
\end{tabular}

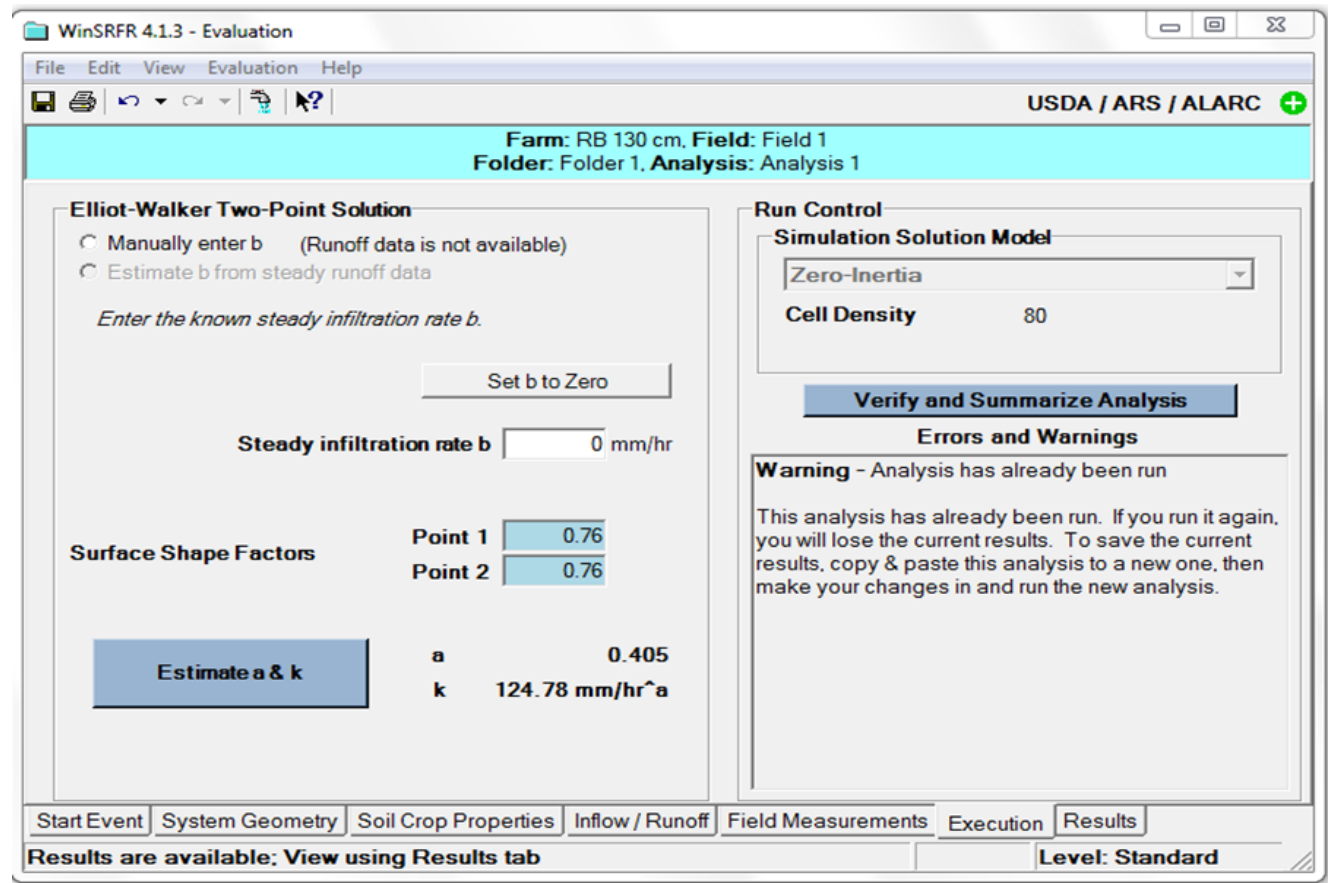

Figure 11: Screenshot of the execution window for the RB $130 \mathrm{~cm}$

\section{Variation of Infiltration Characteristics}

The Event Analysis world (Kostiakov parameters) results for RB130 cm, RB100 cm, and FB irrigation systems were different, where the values of a parameter were $0.405,0.309$, and 
0.208 , respectively. And the $\mathrm{k}$ values for $\mathrm{RB} 130 \mathrm{~cm}, \mathrm{RB} 100 \mathrm{~cm}$, and FB were 124.78 , 147.401 , and $171.759 \mathrm{~mm} / \mathrm{hr}^{\mathrm{a}}$, respectively.

Variation in infiltration parameters due to spatial variation in soil characteristics has been reported by Strelkoff et al., (1999), who stated that changes in soil moisture, compression, and irrigation system, even in the same type of soil, all affect infiltration characteristics. Infiltration is also affected by soil texture, which can vary even within a single field due to spatial variation in soil properties. Xu et al., (2019) reported that soil bulk density and soil moisture content can explain temporal variability in infiltration. Furthermore, the soil structure is continuously disturbed and damaged as a result of cultivation, irrigation, and rainfall, possibly resulting in different values of infiltration parameters.

\section{Simulation Analysis}

Based on infiltration parameters obtained from the Event Analysis World, the simulation analysis world was used to conduct the model calibration based on the appropriate compatibility of the observed advance and recession curves with the simulated ones (The $n$ and $\alpha$ were calibrated to re-run the model until a reasonable match between the two curves were obtained (Li, 2019)).

Figure (12), (13), and (14) show the observed and simulated advance \& recession curve in a single graph showing the degree of convergence between them for RB 130, RB $100 \mathrm{~cm}$, and FB respectively.

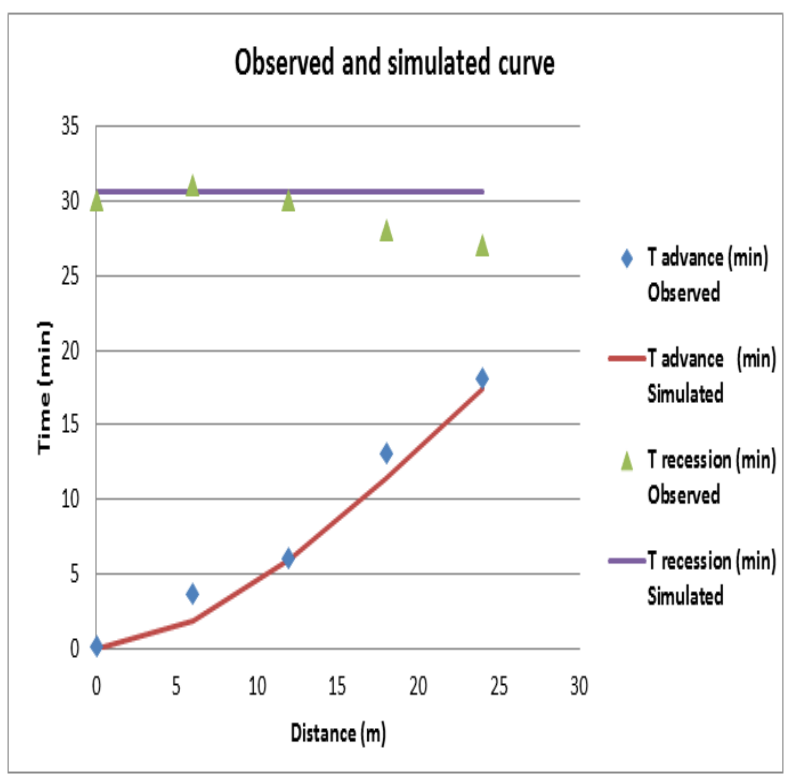

Figure 12: Comparison of observed and simulated advance and recession curve for the $R B 130 \mathrm{~cm}$

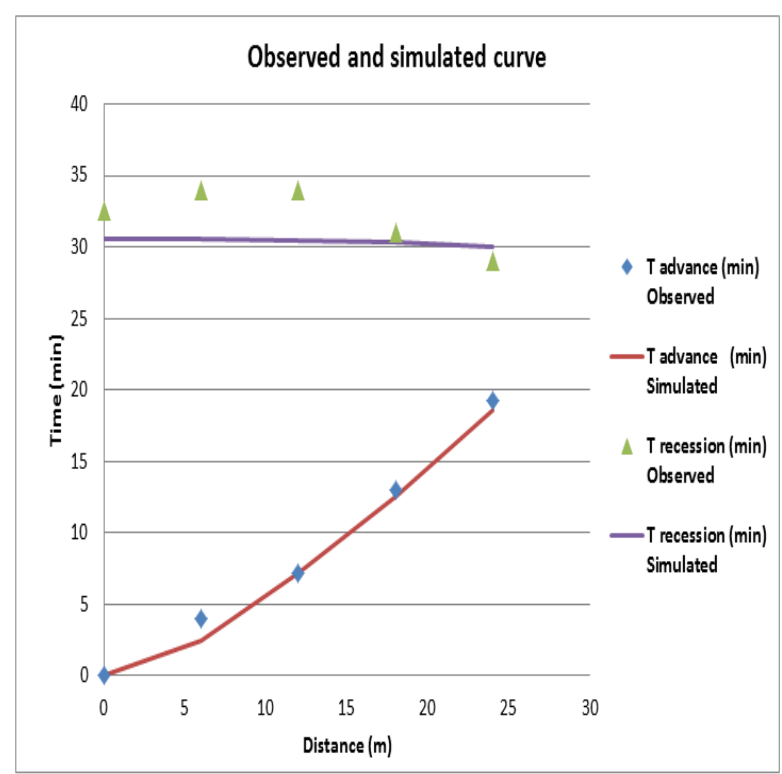

Figure 13: Comparison of observed and simulated advance and recession of $\mathrm{RB} 100 \mathrm{~cm}$

\section{Evaluating Irrigation Performance}

Based on event analysis results (infiltration parameters) in the previous section, in this section, we will use the Simulation Analysis World to evaluate the existing RB furrows and basin irrigation performance. The same a, $\mathrm{n}$ and $\mathrm{k}$ model parameters as the calibrated values in the model testing section will be used here. Following running the WinSRFR model, predicted irrigation efficiency values were obtained by feeding inputs obtained from field measurements in the WinSRFR software. 


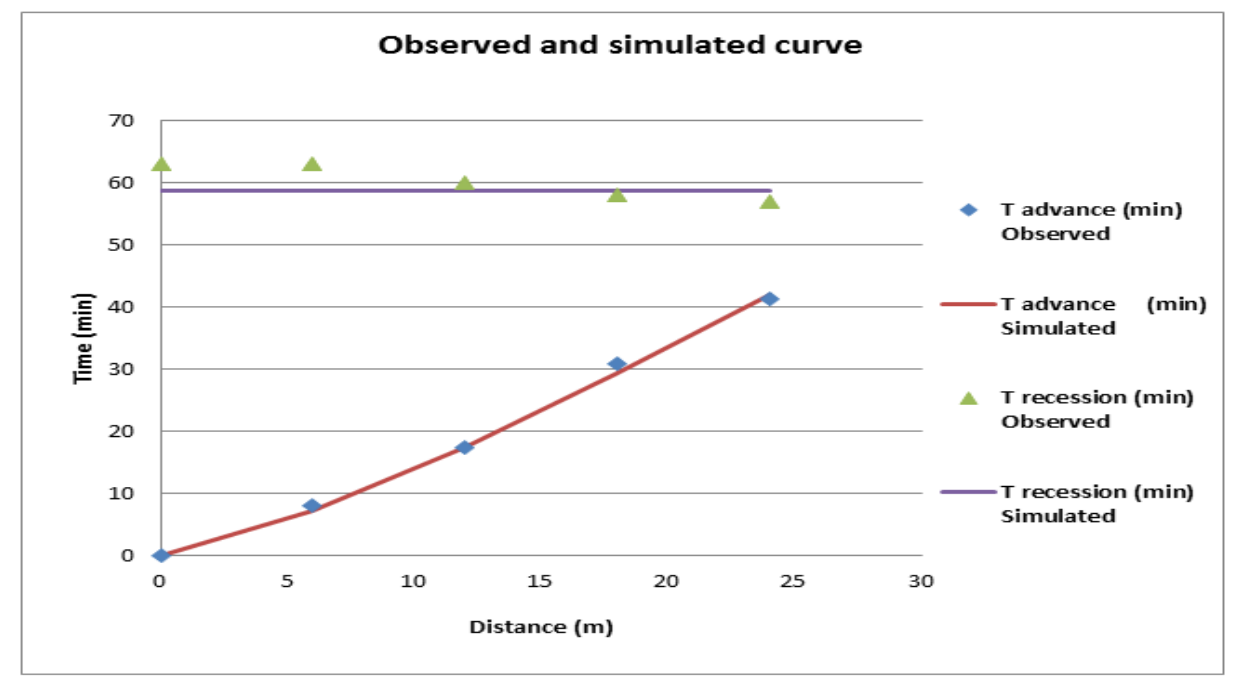

Figure 14: Observed and simulated curve of the advance and recession time for FB

Figure (15) shows Efficiency and uniformity indicators for raised beds and flat basins, the RB130 cm was the highest achieved application efficiency, followed by RB100 cm, while the FB irrigation system was the lowest achieved application efficiency. It is also evident from Fig (15) that the raised beds system achieved the least percentage of deep percolation during irrigation events from a flat basin.

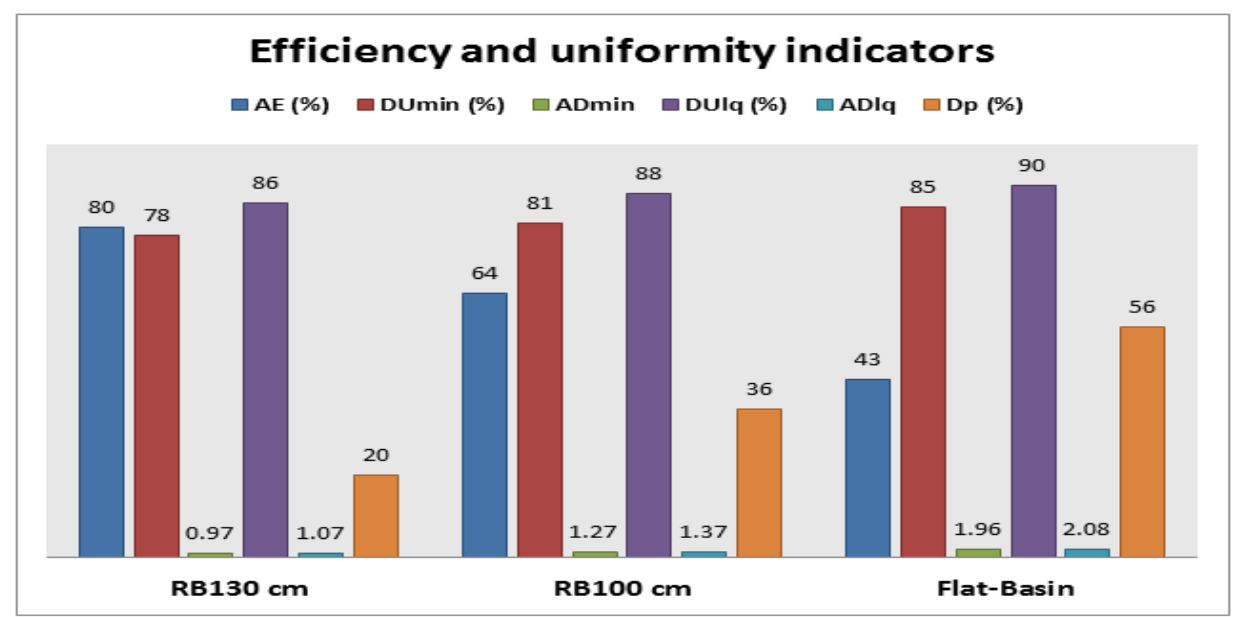

Figure 15: Efficiency and uniformity indicators for raised beds and flat basin during $1^{\text {st }}$ irrigation event

Under the existing field conditions, the current irrigation efficiencies were poor on-farm for raised beds and flat basins, where the application efficiency was 80, 64, and 43\% for RB130 $\mathrm{cm}, \mathrm{RB} 100 \mathrm{~cm}$, and FB, respectively. The present irrigation event was over-irrigated, where the $\mathrm{AD}_{\mathrm{lq}}$ value was above 1 for $\mathrm{RB} 130 \mathrm{~cm}, \mathrm{RB} 100 \mathrm{~cm}$, and $\mathrm{FB}$. Excessive irrigation applications have been lost as deep drainage because the downstream condition was blocked for all fields, as the value of the deep drainage was 20,36 , and $56 \%$ for RB130 cm, RB100 $\mathrm{cm}$, and FB, respectively. The higher $\mathrm{DU}_{\mathrm{lq}}$ or $\mathrm{DU} \mathrm{min}_{\min }$ for $\mathrm{RB} 130 \mathrm{~cm}, \mathrm{RB} 100 \mathrm{~cm}$, and FB indicates that the depth required (Dreq) to fill the root zone was fulfilled with large deep drainage losses. The reason for the low application efficiency was that the large inflow rate with a short field length and a long cutoff time resulted in an amount of applied water that was greater than the required application. So, deep percolation loss could be created. 
These results closely agree with those obtained by (Biru Dechasa Sima, 2018) who said that the results of the current furrow irrigation performance parameters were evaluated by WinSRFR based on design variables including infiltration parameters. This finding revealed low application efficiency (AE) that could have been expected based on variations in opportunity time along the furrows. This is created for all losses where the deep percolation loss (DP) amounted to almost $60 \%$.

Significant variations in irrigation efficiency (AE) were observed between all RB130, RB100 $\mathrm{cm}$, and FB irrigation systems evaluated on farms. As a result, the irrigation system was never optimally designed and operated for variable field conditions and to satisfy the SMDs. This showed us the need to change the current irrigation system design and operate to improve irrigation performance.

\section{Optimizing Irrigation Performance with Physical Design World}

The calibrated infiltration parameters have been used to optimize and develop various design strategies using the Physical Design World of the model. Throughout the optimization process, the model was configured to develop performance contours as a function of width (furrow set/border) and length for a given inflow rate. Performance contours were used to determine the impact of optimizing field width and length on potential application efficiency (PAE $\mathrm{min}_{\mathrm{m}}$ ), distribution uniformity (DU $\mathrm{min}$ ), and deep percolation losses (Dp). After field width and length were optimized using the WinSRFR model, more improvement in irrigation efficiency was explored.

The strategy of optimizing field length and width together using WinSRFR demonstrated that irrigation performance can be improved by optimizing the existing field sizes for the available inflow rate and cutoff time.

\section{Optimizing irrigation performance for $R B 130 \mathrm{~cm}$}

The results shown in Table (3) confirmed that the irrigation efficiency of the RB130 system is very sensitive to field length and width. When the furrow width was $1.3 \mathrm{~m}$, the highest irrigation performance was achieved at a furrow length of $12 \mathrm{~m}$ where $\mathrm{PAE}_{\min }=80 \%, \mathrm{DU}_{\min }=$ $94 \%$, and $\mathrm{DP}=5 \%$. Also, when the furrow width was $2.6,3.9,5.2 \mathrm{~m}$, the highest irrigation performance was achieved at a furrow length of $12 \mathrm{~m}$. The results showed that irrigation performance decreased with increasing furrow length, so extremely long furrow lengths should be avoided because they result in decreased efficiency and uniformity, as well as big deep percolation loss.

The results shown in Fig (16) confirmed that the irrigation efficiency of the RB130 system is very sensitive to field length and width. When the furrow width was $1.3 \mathrm{~m}$, the highest irrigation performance was achieved at a furrow length of $12 \mathrm{~m}$ where $\mathrm{PAE}_{\min }=80 \%, \mathrm{DU}_{\min }=$ $94 \%$, and $\mathrm{DP}=5 \%$. Also, when the furrow width was $2.6,3.9,5.2 \mathrm{~m}$, the highest irrigation performance was achieved at a furrow length of $12 \mathrm{~m}$.

Figure (16) shows the irrigation efficiency of the current design of the RB130 system and the best strategies for optimizing furrow length and width that have achieved the highest irrigation performance. These management strategies have allowed $\mathrm{PAE}_{\min }$ to increase from $76 \%$ to $80,81,82$, and $82 \%$ for furrow widths of $1.3,2.6,3.9$, and $5.2 \mathrm{~m}$, respectively, at 
furrow lengths of $12 \mathrm{~m}$, and $\mathrm{DU}_{\min }$ to increase from $76 \%$ to $94,93,92$ and $90 \%$ for furrow widths of $1.3,2.6,3.9$, and $5.2 \mathrm{~m}$, respectively, at furrow lengths of $12 \mathrm{~m}$, and to reduce DP from $24 \%$ to $5,6,8$ and $9 \%$ for furrow widths of 1.3, 2.6, 3.9, and $5.2 \mathrm{~m}$, respectively, at furrow lengths of $12 \mathrm{~m}$.

Table 3: Optimizing irrigation performance for $R B 130 \mathrm{~cm}$ of a given inflow rate $(Q=15 \mathrm{l} / \mathrm{s})$

\begin{tabular}{|c|c|c|c|c|c|c|c|c|c|c|c|}
\hline \multirow{10}{*}{$\begin{array}{l}\text { है } \\
\text { ले } \\
\text { लै } \\
\text { है }\end{array}$} & \multirow{2}{*}{$\begin{array}{l}\text { Performance } \\
\text { indicators }\end{array}$} & \multicolumn{5}{|c|}{$\mathrm{W}=1.3 \mathrm{~m}($ Number per set $=1)$} & \multicolumn{5}{|c|}{$\mathrm{W}=2.6 \mathrm{~m}($ Number per set $=2)$} \\
\hline & & $\begin{array}{c}\mathrm{L}=12 \\
\mathrm{~m}\end{array}$ & $\begin{array}{c}\mathrm{L}=24 \\
\mathrm{~m}\end{array}$ & $\begin{array}{c}\mathbf{L}=\mathbf{5 0} \\
\mathbf{m}\end{array}$ & $\begin{array}{c}\mathrm{L}=75 \\
\mathrm{~m}\end{array}$ & $\begin{array}{c}\mathrm{L}=\mathbf{1 0 0} \\
\mathrm{m}\end{array}$ & $\begin{array}{c}\mathrm{L}=12 \\
\mathrm{~m}\end{array}$ & $\begin{array}{c}\mathrm{L}=24 \\
\mathrm{~m}\end{array}$ & $\begin{array}{c}\mathbf{L}=\mathbf{5 0} \\
\mathbf{m}\end{array}$ & $\begin{array}{c}\mathrm{L}=75 \\
\mathrm{~m}\end{array}$ & $\begin{array}{c}\mathrm{L}=100 \\
\mathrm{~m}\end{array}$ \\
\hline & PAEmin (\%) & 80 & 78 & 75 & 72 & 68 & 81 & 79 & 74 & 69 & 64 \\
\hline & DUmin $(\%)$ & 94 & 89 & 82 & 77 & 73 & 93 & 87 & 78 & 72 & 66 \\
\hline & Dp (\%) & 5 & 9 & 16 & 21 & 26 & 6 & 11 & 20 & 27 & 33 \\
\hline & & \multicolumn{5}{|c|}{$\mathrm{W}=3.9 \mathrm{~m}($ Number per set $=3)$} & \multicolumn{5}{|c|}{$\mathrm{W}=5.2 \mathrm{~m}($ Number per set $=4)$} \\
\hline & $\begin{array}{l}\text { Performance } \\
\text { indicators }\end{array}$ & $\begin{array}{c}\mathrm{L}=12 \\
\mathrm{~m}\end{array}$ & $\begin{array}{c}\mathrm{L}=\mathbf{2 4} \\
\mathrm{m}\end{array}$ & $\begin{array}{c}\mathbf{L}=\mathbf{5 0} \\
\mathbf{m}\end{array}$ & $\begin{array}{c}\mathbf{L}=\mathbf{7 5} \\
\mathrm{m}\end{array}$ & $\begin{array}{c}\mathrm{L}=\mathbf{1 0 0} \\
\mathbf{m}\end{array}$ & $\begin{array}{c}\mathrm{L}=12 \\
\mathrm{~m}\end{array}$ & $\begin{array}{c}\mathrm{L}=\mathbf{2 4} \\
\mathrm{m}\end{array}$ & $\begin{array}{c}\mathbf{L}=\mathbf{5 0} \\
\mathbf{m}\end{array}$ & $\begin{array}{c}\mathbf{L}=\mathbf{7 5} \\
\mathrm{m}\end{array}$ & $\begin{array}{c}\mathrm{L}=100 \\
\mathbf{m}\end{array}$ \\
\hline & PAEmin $(\%)$ & 82 & 79 & 71 & 64 & 59 & 82 & 78 & 68 & 60 & 54 \\
\hline & DUmin $(\%)$ & 92 & 85 & 74 & 66 & 60 & 90 & 83 & 70 & 61 & 55 \\
\hline & Dp (\%) & 8 & 14 & 25 & 33 & 39 & 9 & 16 & 29 & 38 & 45 \\
\hline
\end{tabular}

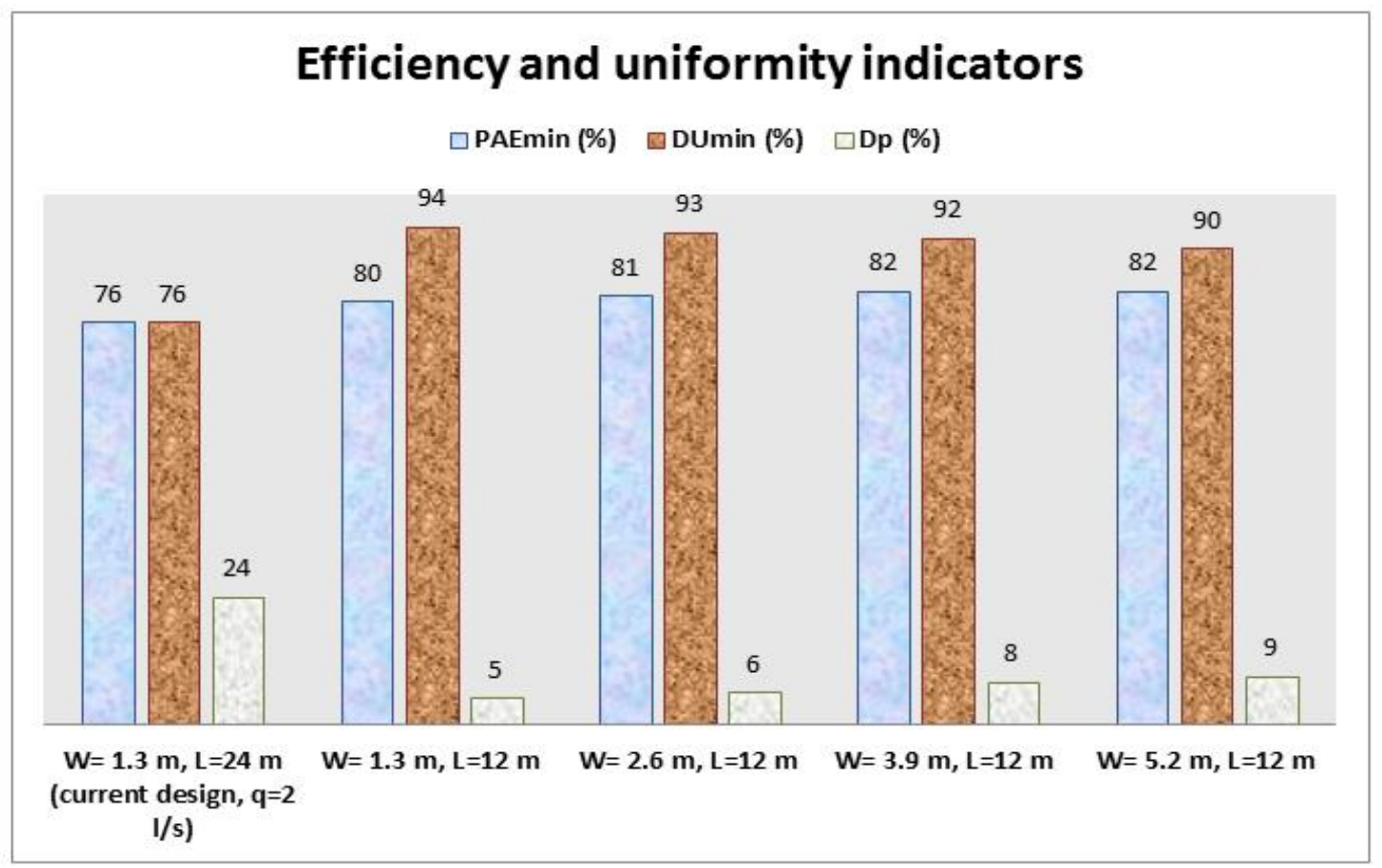

Figure 16: Develop performance contours as a function of length and width for $R B 130 \mathrm{~cm}$

These results agree with those obtained by (Akbar et al., 2016) who reported that findings obtained clearly demonstrated that there is more potential to increase PAE by reducing field length and width.

\section{Optimizing irrigation performance for $R B 100 \mathrm{~cm}$}

The results are shown in Table (4) indicate that the best strategies to obtain high irrigation efficiency at furrow width 1, 2, 3, and $4 \mathrm{~m}$ were achieved when furrow length was $12 \mathrm{~m}$. The results showed that PAE decreased with increased furrow length due to increased deep drainage losses. 
Figure (17) shows the irrigation efficiency of the current design of the RB100 system and the best techniques for maximizing furrow length and width that have achieved the highest irrigation performance. These management techniques have enabled $\mathrm{PAE}_{\min }$ to increase from $68 \%$ to $69,71,72$, and $73 \%$ for furrow widths of $1,2,3$, and $4 \mathrm{~m}$, respectively, at furrow lengths of $12 \mathrm{~m}$, and $\mathrm{DU}_{\min }$ to increase from $68 \%$ to $86,85,83$ and $82 \%$ for furrow widths of $1,2,3$, and $4 \mathrm{~m}$, respectively, at furrow lengths of $12 \mathrm{~m}$, and to reduce DP from $32 \%$ to 12 , 13,15 and $16 \%$ for furrow widths of $1,2,3$, and $4 \mathrm{~m}$, respectively, at furrow lengths of $12 \mathrm{~m}$. The increase in PAE and DU by reducing field length under furrow irrigation closely corresponds to the results found by (Mazarei et al., 2020) who stated that decreased furrow length leads to an increase in the value of the objective function (including application efficiency, distribution uniformity and deep percolation).

Table 4: Optimizing irrigation performance for $\mathrm{RB} 100 \mathrm{~cm}$ of a given inflow rate $(\mathrm{Q}=15 \mathrm{l} / \mathrm{s})$

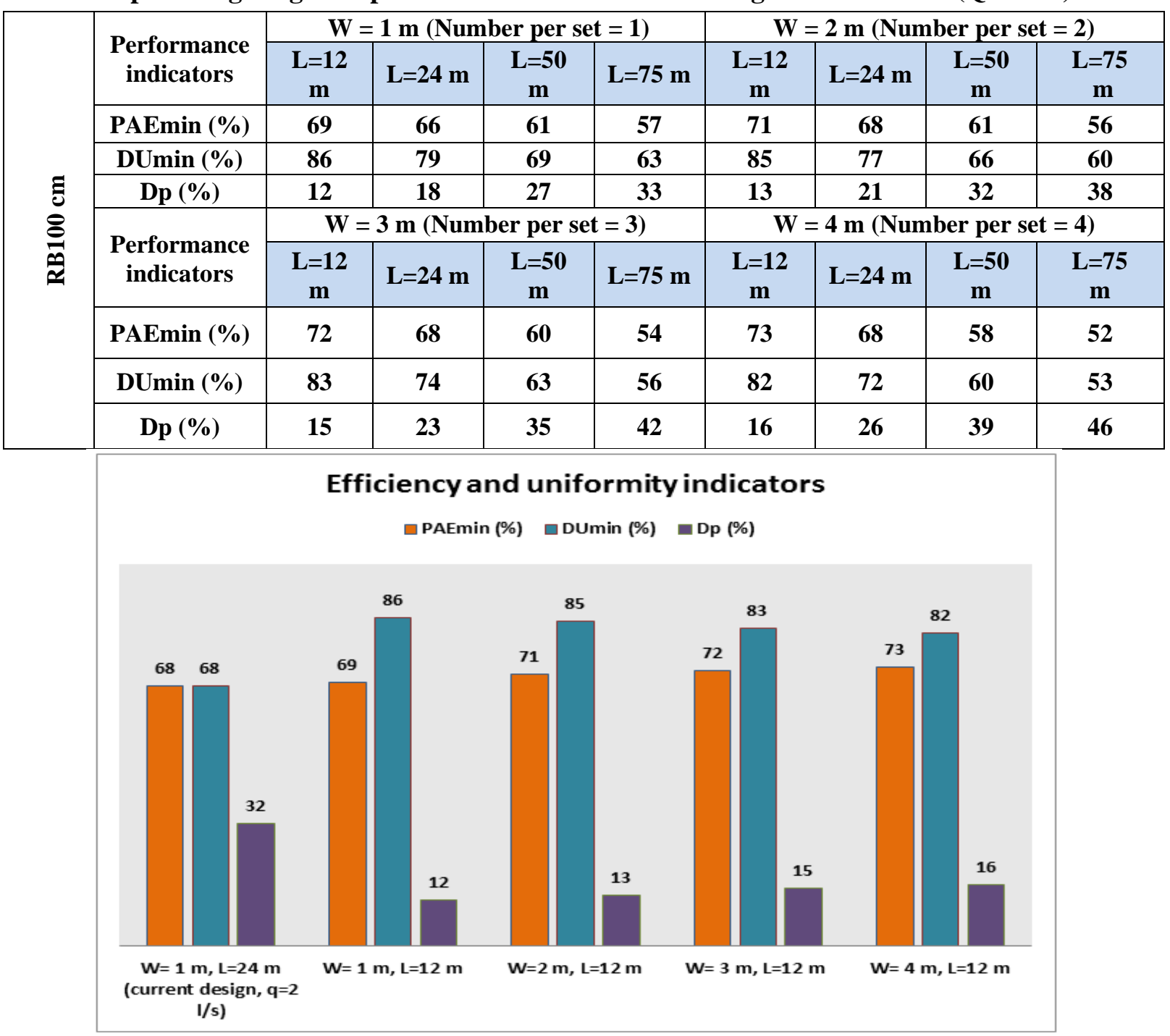

Figure 17: Develop performance contours as a function of length and width for $R B 100 \mathrm{~cm}$

\section{Optimizing irrigation performance for Flat-Basin}

By optimizing the existing basin sizes for the available inflow rate and cut-off time, the irrigation performance can be improved as shown in Table ( ${ }^{\circ}$ ). Figure (18) depicts the irrigation efficiency of the current FB system design as well as the best strategies for 
optimizing basin length and width that have resulted in the best irrigation performance. When the basin width was $1.3 \mathrm{~m}$, the best irrigation performance was obtained at a basin length of $12 \mathrm{~m}$, with $\mathrm{PAE}_{\min }=54 \%, \mathrm{DU}_{\min }=57 \%$, and $\mathrm{DP}=50 \%$. Furthermore, when the basin width was $2.6,3.9$, or $5.2 \mathrm{~m}$, the furrow length of $12 \mathrm{~m}$ also provided the best irrigation performance compared to the other lengths. PAE and DU were found to decrease as basin length and width increased. Large length and width for flat basins should be avoided because they result in poor irrigation performance.

These management strategies have increased $\mathrm{PAE}_{\min }$ from $47 \%$ to 54 and $49 \%$ for basin widths of 1.3 and $2.6 \mathrm{~m}$, respectively, at a basin length of $12 \mathrm{~m}$, and $\mathrm{DU}$ min to rise from $50 \%$ to $57,61,61$, and $58 \%$ for basin widths of $1.3,2.6,3.9$, and $6.5 \mathrm{~m}$, respectively, at a basin length of $12 \mathrm{~m}$, and to reduce DP from $58 \%$ to 50 , and $56 \%$ for basin widths of 1.3 , and 2.6 $\mathrm{m}$, respectively, at basin lengths of $12 \mathrm{~m}$.

Table 5: Optimizing irrigation performance for $\mathrm{FB}$ of a given inflow rate

\begin{tabular}{|c|c|c|c|c|c|c|c|c|c|c|c|}
\hline \multirow{10}{*}{ 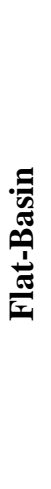 } & \multirow{2}{*}{$\begin{array}{l}\text { Performance } \\
\text { indicators }\end{array}$} & \multicolumn{5}{|c|}{$\mathrm{W}=1.3 \mathrm{~m}$} & \multicolumn{5}{|c|}{$\mathrm{W}=2.6 \mathrm{~m}$} \\
\hline & & $\begin{array}{c}\mathrm{L}=12 \\
\mathrm{~m}\end{array}$ & $\begin{array}{c}\mathrm{L}=\mathbf{2 4} \\
\mathrm{m}\end{array}$ & $\begin{array}{c}\mathbf{L}=\mathbf{5 0} \\
\mathbf{m}\end{array}$ & $\begin{array}{c}\mathrm{L}=75 \\
\mathrm{~m}\end{array}$ & $\begin{array}{c}\mathrm{L}=100 \\
\mathrm{~m}\end{array}$ & $\begin{array}{c}\mathrm{L}=12 \\
\mathrm{~m}\end{array}$ & $\begin{array}{c}\mathrm{L}=\mathbf{2 4} \\
\mathrm{m}\end{array}$ & $\begin{array}{c}\mathbf{L}=\mathbf{5 0} \\
\mathbf{m}\end{array}$ & $\begin{array}{c}\mathrm{L}=75 \\
\mathrm{~m}\end{array}$ & $\begin{array}{c}\mathrm{L}=\mathbf{1 0 0} \\
\mathrm{m}\end{array}$ \\
\hline & PAEmin (\%) & 54 & 48 & 46 & 42 & 39 & 49 & 51 & 44 & 40 & 37 \\
\hline & DUmin $(\%)$ & 57 & 52 & 46 & 42 & 40 & 61 & 55 & 44 & 40 & 37 \\
\hline & Dp (\%) & 50 & 52 & 54 & 58 & 61 & 56 & 54 & 56 & 60 & 63 \\
\hline & & \multicolumn{5}{|c|}{$\mathrm{W}=3.9 \mathrm{~m}$} & \multicolumn{5}{|c|}{$\mathrm{W}=6.5 \mathrm{~m}$} \\
\hline & $\begin{array}{l}\text { Pertormance } \\
\text { indicators }\end{array}$ & $\begin{array}{c}\mathrm{L}=12 \\
\mathrm{~m}\end{array}$ & $\begin{array}{c}\mathrm{L}=\mathbf{2 4} \\
\mathrm{m}\end{array}$ & $\begin{array}{c}\mathbf{L}=\mathbf{5 0} \\
\mathbf{m}\end{array}$ & $\begin{array}{c}\mathrm{L}=75 \\
\mathrm{~m}\end{array}$ & $\begin{array}{c}\mathrm{L}=100 \\
\mathrm{~m}\end{array}$ & $\begin{array}{c}\mathrm{L}=12 \\
\mathbf{m}\end{array}$ & $\begin{array}{c}\mathrm{L}=\mathbf{2 4} \\
\mathrm{m}\end{array}$ & $\begin{array}{c}\mathbf{L}=\mathbf{5 0} \\
\mathbf{m}\end{array}$ & $\begin{array}{c}\mathrm{L}=75 \\
\mathrm{~m}\end{array}$ & $\begin{array}{c}\mathrm{L}=100 \\
\mathbf{m}\end{array}$ \\
\hline & PAEmin (\%) & 47 & 4 & 42 & 38 & 35 & 46 & 47 & 39 & 35 & 33 \\
\hline & DUmin $(\%)$ & 61 & 53 & 42 & 38 & 35 & 58 & 50 & 39 & 35 & 33 \\
\hline & Dp (\%) & 58 & 56 & 58 & 62 & 65 & 59 & 58 & 61 & 65 & 68 \\
\hline
\end{tabular}

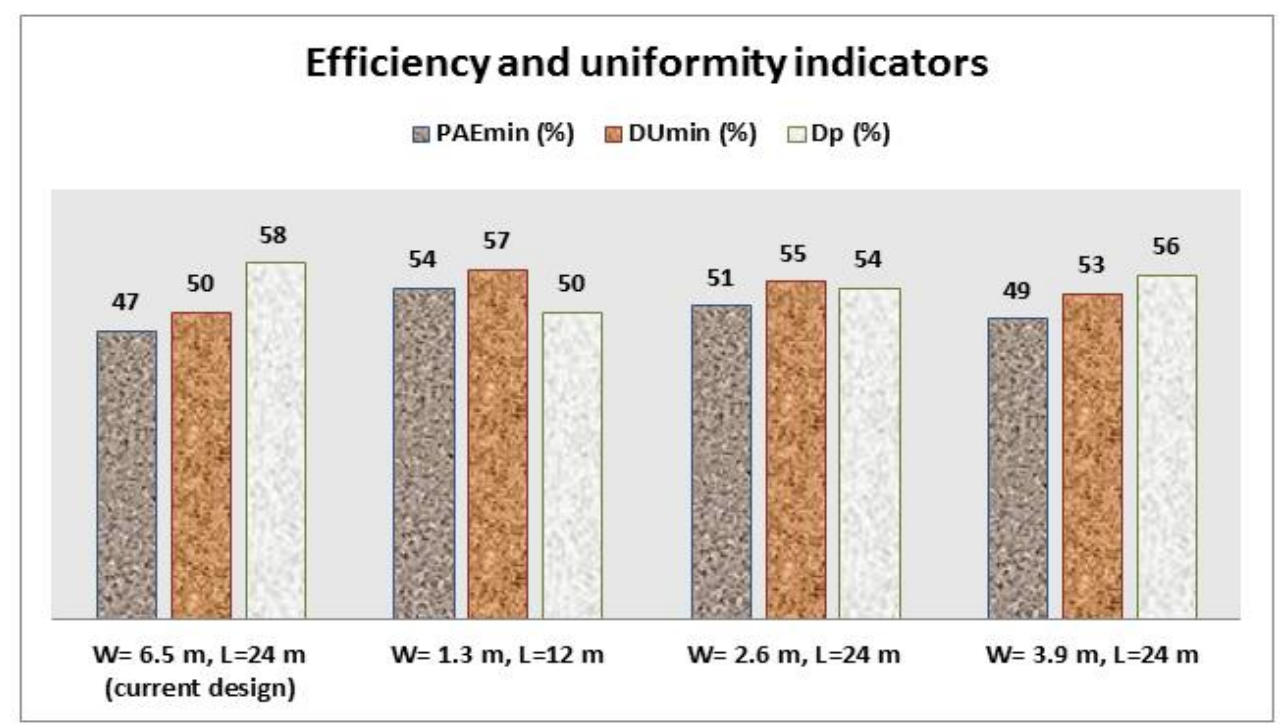

Figure 18: Develop performance contours as a function of length and width for FB

The results showed that irrigation performance decreased with increasing furrow length, so a very long furrow length should be avoided because it leads to reduced efficiency and uniformity, and also huge deep percolation loss.

Understanding the previous optimization of field sizes leads to a better understanding of the interactions between field sizes and irrigation efficiencies, which may aid irrigators in making 
decisions to improve irrigation performance without any significant cost to infrastructure, labor, or machinery (Akbar et al., 2016).

\section{Optimizing Irrigation Performance with Operation Analysis World}

The main objective of the WinSRFR software is to help find a strategy for managing surface irrigation leading to a satisfactory level of efficiency. These strategies may be a decrease in the flow rate and its time of application. According to (Mazarei et al., 2020), it is easy for growers to adjust flow discharge and cutoff time compared to soil properties modification and field design.

The calibrated infiltration parameters have been used to optimize and develop various operation strategies using the Operation analysis World of the model. In the optimization phase, the model was configured to develop performance contours as a function of inflow rate and cutoff time for the known width (number of furrows per set /border). Performance contours were used to determine the impact of optimizing inflow rate and cutoff time on application irrigation efficiency (AE), distribution uniformity ( $\mathrm{DU}_{\mathrm{min}}$ ), and deep percolation losses (DP).

\section{Optimizing irrigation efficiency for $\mathrm{RB} 130 \mathrm{~cm}, \mathrm{RB} 100$ and FB}

Figures (19, 20, and 21) illustrate the irrigation efficiency of the existing RB130, RB100 cm, and FB respectively, and the best strategies for maximizing inflow rate and time to the cutoff that has resulted in the best irrigation performance. The analysis indicates that optimizing inflow rate could increase application efficiency by more than $15 \%, 17 \%, 23 \%$, and decrease deep percolation up to $60 \%, 33 \%$, and $17.5 \%$ for RB130, RB100 cm, and FB respectively. For RB130, and RB100 cm the maximum irrigation application efficiency and minimum deep percolation loss were obtained for an inflow rate of $2 \mathrm{l} / \mathrm{s}$ and a cutoff time of $0.30 \mathrm{hr}$, while inflow rate of $18 \mathrm{l} / \mathrm{s}$ and a cutoff time of $0.31 \mathrm{hr}$ for FB. However, knowing the specific values is less essential than understanding the Q-Tco relationship that optimizes both AE and DUmin (N. Pascual-Seva et al., 2013). These findings are consistent with those obtained by Bautista et al. (2013). Mazarei et al., (2021) the results indicated that under higher inflow rates, the AE values decreased while the DP increased. The results reveal that a very low inflow rate associated with a shorter cutoff time must be avoided because it will result in incomplete irrigation water advance.

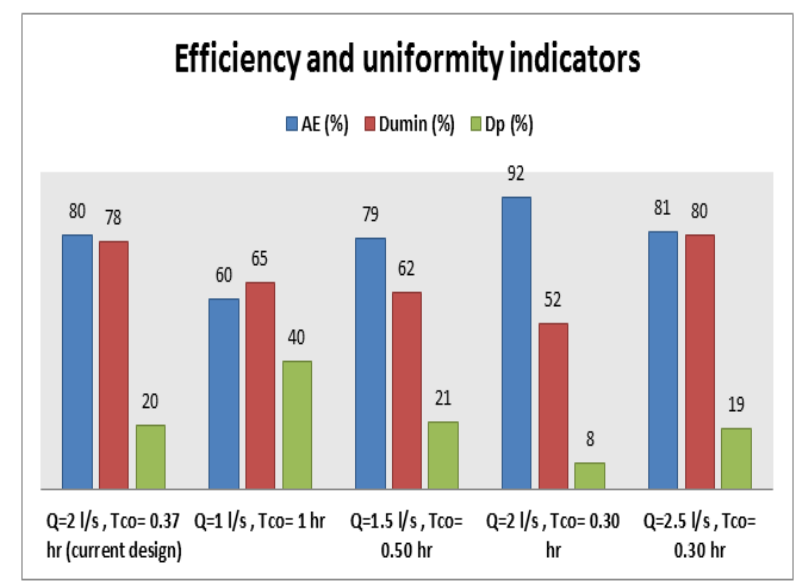

Figure 19: Develop performance contours as a function of inflow rate and cutoff time for RB $130 \mathrm{~cm}$

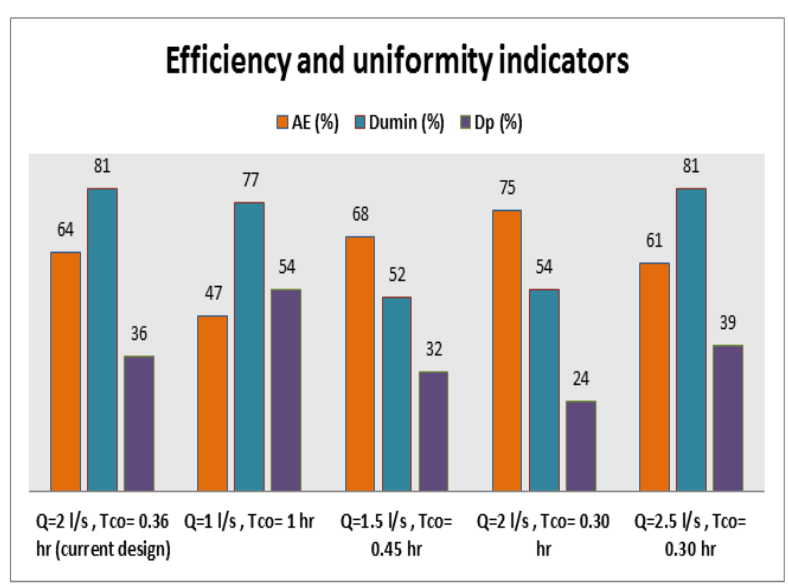

Figure 20: Develop performance contours as a function of inflow rate and cutoff time for $\mathrm{RB}$ $100 \mathrm{~cm}$ 


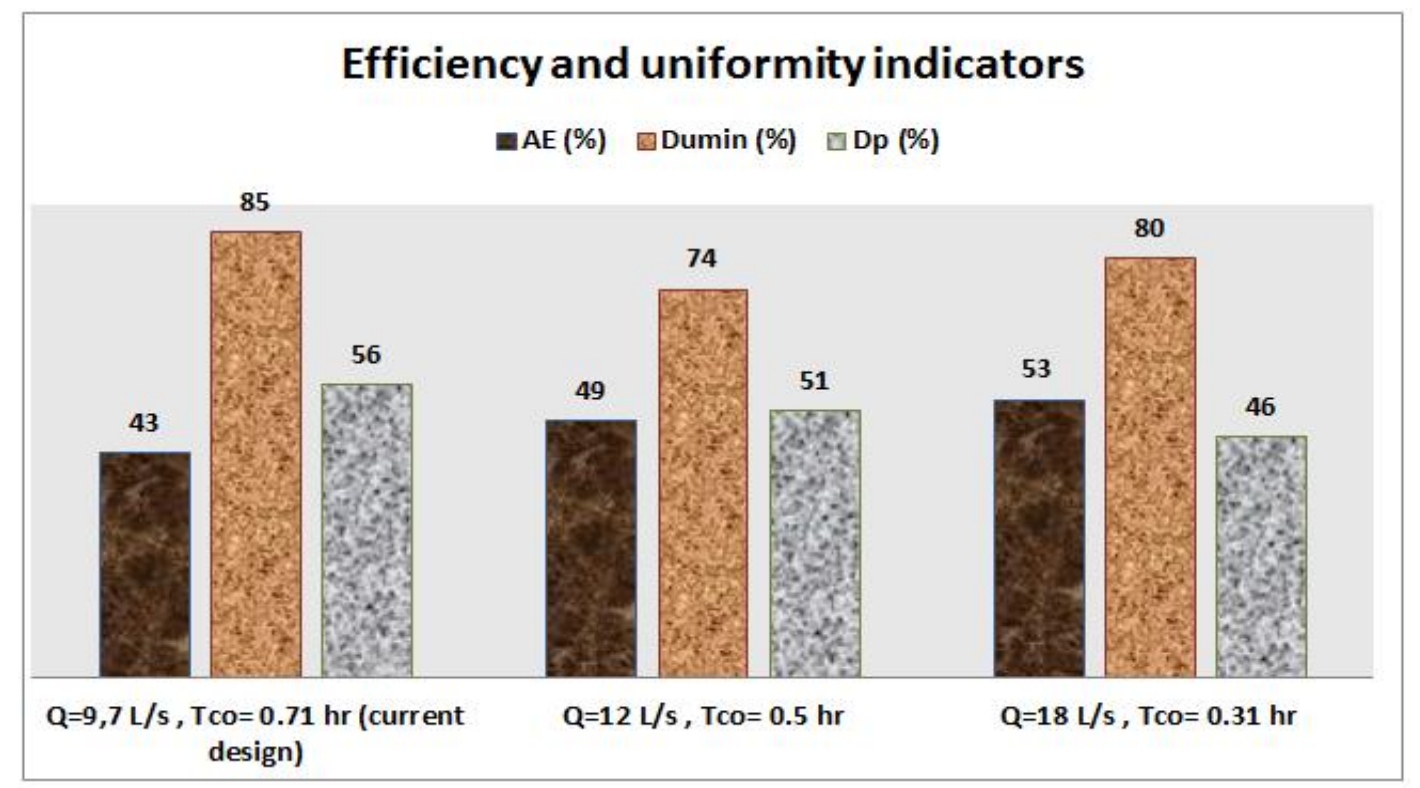

Figure 21: Develop performance contours as a function of inflow rate and cutoff time for FB irrigation system

\section{RECOMMENDATION}

The following recommendations were drawn for the study of evaluating, optimizing the design, and managing the operation of raised bed furrow and flat basin irrigation systems:

1. When compared to field tests, WinSRFR can assist the designer in determining the appropriate values of the variables that will provide the best irrigation performance at the lowest cost and in the shortest time.

2. Based on the results of evaluating irrigation performance for raised beds and flat basin using Simulation Analysis World, farmers should use the RB130 cm method because it achieved higher irrigation performance than the RB100 cm and FB methods.

3. According to Physical Design Analysis, increasing the length of the furrow and flat basin reduces irrigation performance, so a very long length should be avoided because it leads to reduced efficiency and uniformity, as well as huge deep percolation loss.

4. According to the analysis, managing the inflow rate and irrigation cutoff can increase application efficiency and reduce deep percolation losses by more than $15 \%, 60 \%$ for RB $130 \mathrm{~cm}$, and $17 \%, 33 \%$ for $\mathrm{RB} 100 \mathrm{~cm}$, and $23 \%, 17.5 \%$ for FB irrigation system, respectively.

5. Using Operation Analysis World, the optimal inflow rate and cutoff time is recommended as $2 \mathrm{~L} / \mathrm{s}$ and $0.30 \mathrm{hr}$ for RB130 cm and RB100 cm, and $18 \mathrm{~L} / \mathrm{s}$ and $0.31 \mathrm{hr}$ for FB method.

6. We recommend that concerned government agencies spread raised bed cultivation in the old lands by making more improvements to this method in order to achieve the highest productivity and irrigation water savings under Egyptian conditions, as well as work to provide farmers with affordable raised bed cultivated machinery. 


\section{ACKNOWLEDGEMENTS}

The authors gratefully to the ICARDA Cairo Office and the Sakha Agricultural Research Station for their generous technical and financial assistance during the experiment's implementation at the Sakha Agricultural Research Station farm.

\section{REFERENCES}

Akbar, G., et al. (2016). Irrigation efficiencies potential under surface irrigated farms in Pakistan. Journal of Engineering and Applied Sciences, 35(2), 15-24.

Akbar, G., et al. (2017). Strategies to Improve the Irrigation Efficiency of Raised Beds on Small Farms. Sarhad Journal of Agriculture, 33(4). https://doi.org/10.17582/journal.sja/2017/33.4.615.623

Bautista, E., et al. (2009). Modern analysis of surface irrigation systems with WinSRFR. Agric Water Management, 96(7), 1146-1154.

Bautista, E., Schlegel, J. L., (2019). WinSRFR 5.1-user manual. USDA-Agricultural Research Service Arid Land Agricultural Research Center 21881 North Cardon Lane Maricopa, AZ, USA 85138. https://data.nal.usda.gov/system/files/WinSRFR5.pdf

Bautista, E., Schlegel, J., \& Strelkoff, T. (2012). WinSRFR 4.1, Software and User Manual. Arid Land Agricultural Research Center Maricopa, 21881, 10-14.

Biru, D. S. (2018). Evaluation of Hydraulic Performance and Optimal Design of Furrow Irrigation Using SIRMOD and WinSRFR Software's: The Case of Awash Melkessa. (Doctoral dissertation), Adama Science and Technology University, Ethiopia 2018.

Clemmens, A. J., Dedrick, A. R., \& Strand, R. J. (1995). BASIN-a computer program for the design of level-basin irrigation systems, version 2.0, WCL Report 19. US Water Conservation Laboratory, Phoenix, Arizona.

El-Beltagy, A.T., and Abo-Hadeed A.F. (2008). The main pillars of the National Program for maximizing the water-use efficiency in the old land. $30 \mathrm{p}$. The Research and Development Council. Ministry of Agriculture and Land Reclamation (MOALR), Giza, Egypt (in Arabic).

El-Halim, A. (2013). Impact of alternate furrow irrigation with different irrigation intervals on yield, water use efficiency, and economic return of corn. Chilean journal of agricultural research, 73(2), 175-180. https://doi.org/10.4067/S0718-58392013000200014

Geeves, G. W., et al. (199•). Productivity and sustainability from managing soil structure in cropping soils of southern NSW and northern Victoria with lighter-textured surfaces.

Jurriëns, M., et al. (2001). SURDEV: surface irrigation software; design, operation, and evaluation of basin, border, and furrow irrigation (No. 59). International Institute for Land Reclamation and Improvement/ILRI. 
Harun-ur-Rashid, M., 1990. "Estimation of Manning's roughness coefficient for basin and border irrigation," Agricultural Water Management, Elsevier, vol. 18(1), pages 29-33, May.

Khalifa, E. S., Okasha, A., \& Shawat, S. (2019). Development of Surface Irrigation Using Surge Irrigation Technique. Journal of Fresenius Environmental Bulletin, 28(4 A), 3121-3130.

Klute, A.C (1987). Methods of Soil Analysis, Part 1 (Physical and Mineralogical Methods). Agronomy Monograph Nr. 9, Second Edition. Verlag Amer. Soc. Agron. und Soil Sci. Soc. Amer., Madison (Wisconsin), USA. https://doi.org/10.1002/jpln.19871500519

Mazarei, R., et al. (2020). Optimization of furrow irrigation performance of sugarcane fields based on inflow and geometric parameters using WinSRFR in Southwest of Iran. Agricultural Water Management, 228, 105899.

Mazarei, R., Mohammadi, A. S., Naseri, A. A., Ebrahimian, H., \& Izadpanah, Z. (2020). Optimization of furrow irrigation performance of sugarcane fields based on inflow and geometric parameters using WinSRFR in Southwest of Iran. Agricultural Water Management, 228(June 2019), 105899. https://doi.org/10.1016/j.agwat.2019.105899

Mazarei, R., Soltani Mohammadi, A., Ebrahimian, H., \& Naseri, A. A. (2021). Temporal variability of infiltration and roughness coefficients and furrow irrigation performance under different inflow rates. Agricultural Water Management, 245(November). https://doi.org/10.1016/j.agwat.2020.106465

Pascual-Seva, N., et al. (2013). Furrow-irrigated chufa crops in Valencia ( Spain ). II : Performance analysis and optimization. Spanish Journal of Agricultural Research, 11(1), 268-278.

Peter Waller, M. Y. (1994). Irrigation and Drainage Engineering. In Springer International Publishing (Vol. 67, Issue 803).

Roth, C. H., et al. (2005). Evaluation and performance of permanent raised bed cropping systems in Asia, Australia and Mexico. Proceedings of a workshop held in Griffi th, Australia, 1-3 March 2005. ACIAR Proceedings No. 121.

Selim, T. (2011). The effect of land use on soil infiltration rate in a heavy clay soil in Egypt. Vatten, 67(1998), 161-166.

http://www.tidskriftenvatten.se/mag/tidskriftenvatten.se/dircode/docs/48_article_4454.pdf

Strelkoff, T. S., \& Clemmens, A. J. (2007). Hydraulics of surface systems. In Design and Operation of Farm Irrigation Systems, 2nd Edition (pp. 436-498). American Society of Agricultural and Biological Engineers.

Strelkoff, T. S., et al. (1996). BORDER: A design and management aid for sloping border irrigation systems. WCL Report, 21. 
Ismail S. (1993). Optimal irrigation and wheat yield response to applied water. Journal of King Saud University 5:41-56.

Strelkoff, T. S., et al. (1999). Surface-irrigation evaluation models: Application to level basins in Egypt. Transactions of the American Society of Agricultural Engineers, 42(4), 1027-1036. https://doi.org/10.13031/2013.13250

Swelam, A. (2017). Raised-bed planting in Egypt: an affordable technology to rationalize water use and enhance water productivity. November. https://apps.icarda.org/wsInternet/wsInternet.asmx/DownloadFileToLocal?filePath=Science _Impacts/science_impact_raised_bed.pdf\&fileName=science_impact_raised_bed.pdf

Waller, P., \& Yitayew, M. (2015). Irrigation and drainage engineering. Springer.

$\mathrm{Xu}$, J., et al. (2019). Evaluation and optimization of border irrigation in different irrigation seasons based on temporal variation of infiltration and roughness. Agricultural Water Management, 214 (23), 64-77. https://doi.org/10.1016/j.agwat.2019.01.003 


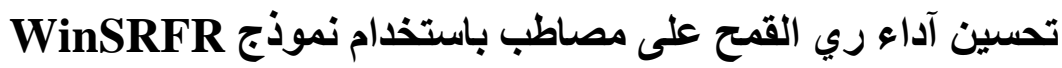

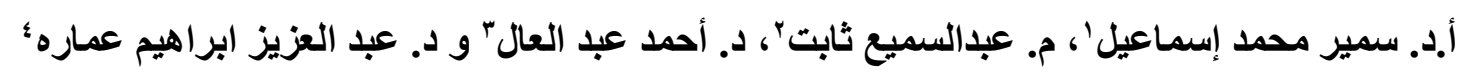

' استاذ هندسة الري و الصرف ـ قلمم الهندسة الزر اعية و النظم الحيوية ـ كلية الزر اعة ـ جامعة الأسكندرية ـ مصر.

r طالب ماجستير ـ قسم الهندسة الزر اعية والنظم الحيوية ـ كلية الزر اعة ـ جامعة الأسكندرية ـ مصر.

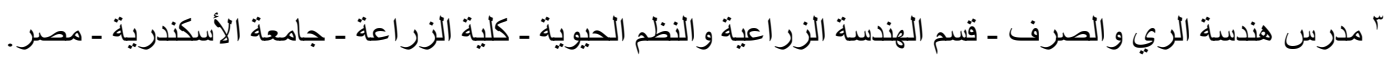

؛ استاذ مساعد هندسة الري و الصرف ـ قسم الهندسة الزر اعية والنظم الحيوية ـ كلية الزر اعة ـ جامعة الأسكندرية ـ مصر.

أجريت تجارب حقلية بمحطة البحوث الزراعية في سخا بمحافظة كفر الشيخ خلال

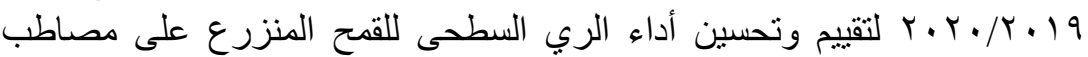

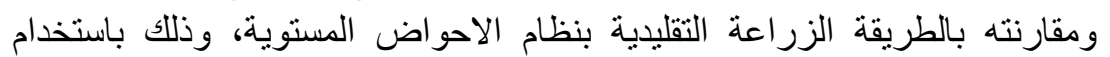

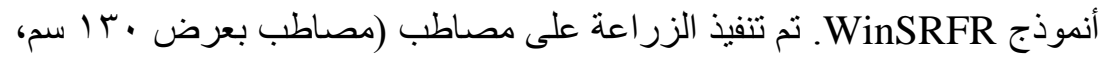

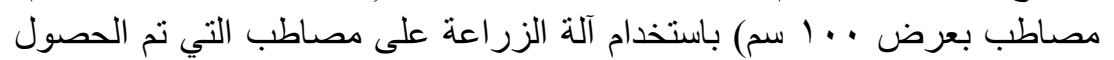

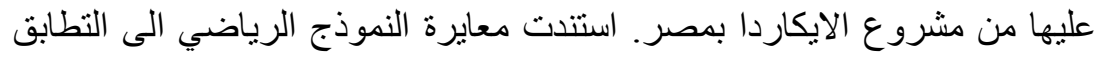

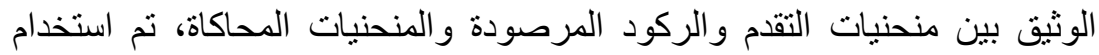

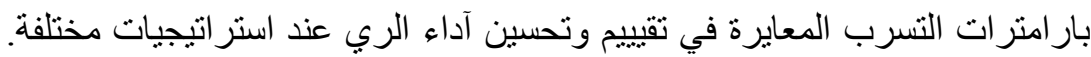

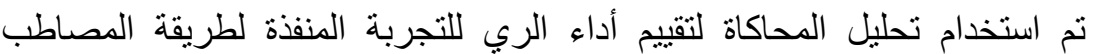

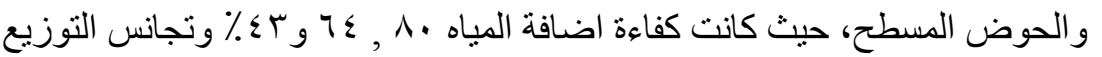

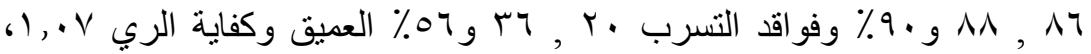

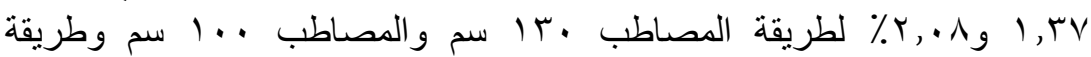

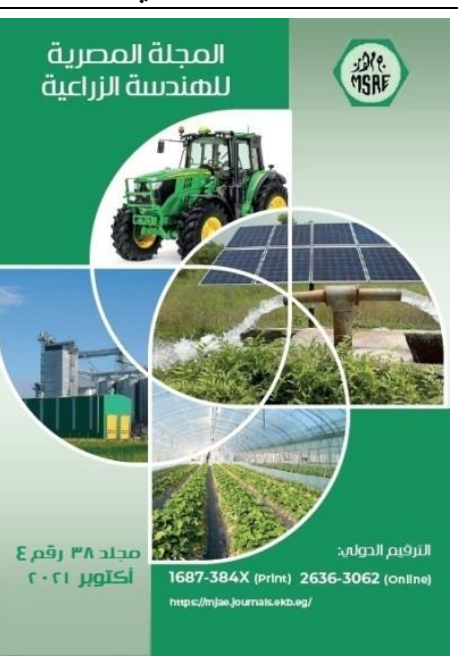

() المجلة المصرية للهندسة الزراعية

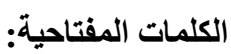
الزراعة على مصاطب، أداء الري، النفئ

التحسين، WinSRFR

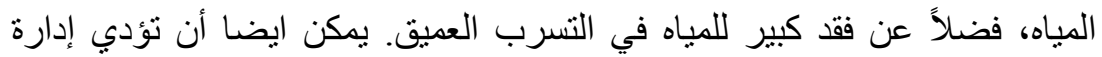
معدل التدفق وزمن الري من خلال النموذج الرياضي إلى زيادة كفاءة اضافة المياه

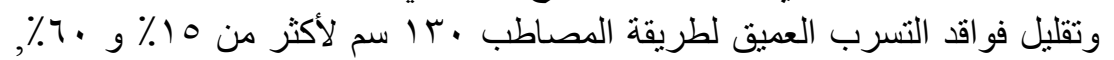

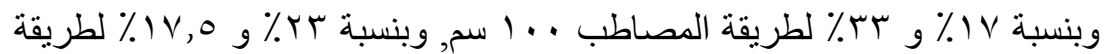

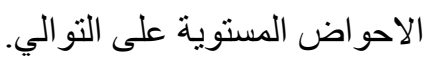

